NBER WORKING PAPER SERIES

\title{
BUILDING BETTER RETIREMENT SYSTEMS IN THE WAKE OF THE GLOBAL PANDEMIC
}

\author{
Olivia S. Mitchell
}

Working Paper 27261

http://www.nber.org/papers/w27261

\author{
NATIONAL BUREAU OF ECONOMIC RESEARCH \\ 1050 Massachusetts Avenue \\ Cambridge, MA 02138 \\ May 2020
}

Prepared for the 2020 Stockholm Conference on "Consumer Behavior in Financial Markets," and the 2020 NBER Conference on "Pension Design and Population Aging." The author acknowledges research support from the Pension Research Council and Boettner Center for Retirement Research at The Wharton School of the University of Pennsylvania. Without implicating them, I am grateful for useful comments provided by Robert Clark, Gene Dykes, Irina Gemmo, Abigail Hurwitz, Mike Orszag, Orly Sade, and Jon Skinner. This research is part of the NBER programs on Aging and Labor Economics, and the Household Finance working group. Opinions expressed herein are those of the author and not those of any institution with which the author is affiliated. (02020 Mitchell. All Rights Reserved The views expressed herein are those of the author and do not necessarily reflect the views of the National Bureau of Economic Research.

The author has disclosed a financial relationship of potential relevance for this research. Further information is available online at http://www.nber.org/papers/w27261.ack

NBER working papers are circulated for discussion and comment purposes. They have not been peer-reviewed or been subject to the review by the NBER Board of Directors that accompanies official NBER publications.

(C) 2020 by Olivia S. Mitchell. All rights reserved. Short sections of text, not to exceed two paragraphs, may be quoted without explicit permission provided that full credit, including () notice, is given to the source. 
Building Better Retirement Systems in the Wake of the Global Pandemic

Olivia S. Mitchell

NBER Working Paper No. 27261

May 2020

JEL No. G23,G51,G53,H55,J26,J32

\section{ABSTRACT}

In the wake of the global pandemic known as COVID-19, retirees, along with those hoping to retire someday, have been shocked into a new awareness of the need for better risk management tools to handle longevity and aging. This paper offers an assessment of the status quo prior to the spread of the coronavirus, evaluates how retirement systems are faring in the wake of the shock. Next we examine insurance and financial market products that may render retirement systems more resilient for the world's aging population. Finally, potential roles for policymakers are evaluated.

Olivia S. Mitchell

University of Pennsylvania

The Wharton School

3620 Locust Walk, St 3000 SH-DH

Philadelphia, PA 19104-6302

and NBER

mitchelo@wharton.upenn.edu 


\title{
Building Better Retirement Systems in the Wake of the Global Pandemic
}

\author{
Olivia S. Mitchell
}

It would have been understandable if, on January 1 of 2020, retirement system sponsors around the world felt at least a bit optimistic about their ability to provide retirement security to the world's aging population. International capital markets had largely rebounded from the 200809 Global Financial Crisis (GFC), albeit with some weaknesses. Unemployment had plummeted after the GFC, and few experts foresaw recession on the horizon. A mere five months later, however, the COVID-19 virus changed everything. Amid the pandemic's spread, capital market values shuddered, healthcare systems staggered with millions of infected patients, joblessness shot up, retirement funding shrank, government tax revenue contracted, and unprecedented government spending had become the new normal. Still unknown is how the world will pay for the trillions in stimulus efforts rolled out amid a massive global recession; fewer still have thought about how global retirement systems will need to be reimagined in the wake of the global pandemic.

This paper offers perspective about how to build more resilient retirement systems, outlining innovative pension designs for both the public and private sectors in developed as well as developing economics. Undoubtedly, the pandemic's economic fallout will be far worse in poorer nations, and the recovery slower, as their healthcare systems are ill-equipped to contain the damages and their national budgets are more strapped. Yet the fact remains that the twin trends of declining fertility and rising longevity will continue to spur the growth of aging populations around the world, for whom retirement systems are going to be increasingly important as a source of oldage income. 
In what follows, I first offer a brief synopsis of where retirement programs stood on the eve of the pandemic. Next, I outline some of the actual and anticipated impacts of the COVID-19 shock to both the global macroeconomy and retirement systems around the world. Then I introduce a set of ideas that could strengthen retirement programs as they help workers build assets supportive of retirement security and help retirees manage their money during the decumulation phase. This is followed by a discussion of how policymakers might wish to bring greater resiliency to retirement systems, along with thoughts about efforts to support people as they plan and save for retirement, invest, and manage their payouts.

\section{Retirement Systems Pre-COVID-19}

\section{A. The Legacy of the Global Financial Crisis (GFC)}

The GFC of 2008-9 brought into sharp focus several factors threatening public and private pension systems. For one thing, while people were living longer, very few worked sufficiently long to offset their rising need for retirement spending (OECD 2019; see Figure 1). The fact that the elderly are spending more years in retirement has resulted in worsening pension funding patterns, meaning that revenues received to support payouts have fallen below those needed to maintain solvency. Indeed, the World Economic Forum (2017: 7) estimated that "[t]he retirement savings gap ...will grow by $5 \%$ each year to $\sim \$ 400$ trillion by 2050 . This means an additional $\$ 28$ billion of deficit each day.”

Figure 1 here

Many of the most troubled pension systems around the world are of the defined benefit (DB) variety, where the benefit formula depends on workers' years of service and labor earnings (IRS, 2020). For instance, the (now frozen) General Motors unionized workers defined benefit 
plan paid a basic monthly benefit equal to $\$ 54$ multiplied by the individual’s work years if he were to claim his benefit after 29 years of service, minus an early retirement penalty and a $\$ 771 /$ month supplement: his total benefit would then be $\$ 1,766 /$ month. If he deferred claiming by just one year, he would have received a "30 and out” supplement boosting his monthly benefit by almost 80\%, to $\$ 3,170$ (United Auto Workers 2018). Most state and local government pensions, as well as numerous national pensions, are also of the defined benefit variety, though the benefit formulas vary widely and at least some are moving to the defined contribution model (Aubrey and Wandrei 2020). ${ }^{1}$

DB plans around the world have long been facing rising underfunding, in part due to an aging population driving higher retiree benefit claims despite a shrinking working age population on which contributions (or taxes) can be levied. Plan fiduciaries have also been accused of using inaccurate assumptions when projecting pay increases and retiree longevity, resulting in benefit payments exceeding what had been anticipated (and financed). ${ }^{2}$ Still another source of DB pension pressure is that plan sponsors frequently have failed to deposit their so-called required contributions in the plans, leading to persistent underfunding. ${ }^{3}$ Moreover, DB plans have tended to invest in risky assets including equities, hedge funds, and alternative investments, none of which were selected to defease, or match, benefit promises. This led to substantial asset meltdowns during the GFC (and more recently as well). Prior to the COVID-19 market downturn, US public DB plan underfunding had escalated to \$4 trillion (Rauh 2017). Around the same time, Citi (2016)

\footnotetext{
${ }^{1}$ In many European nations, the pension scheme uses a points system, where workers accrue points computed by dividing annual pay by the "cost" of a pension point. By contrast, in a notional accounts system, each worker's pay is multiplied by a contribution rate credited to his account using a notional interest rate. In both the latter cases, the accrued points or notional accounts are annuitized to determine the monthly benefit (OECD 2005: 71).

${ }^{2}$ Here we can only mention in passing the heated arguments regarding the choice of discount rate used by DB plan actuaries to compute their liabilities; see Gold (2015).

${ }^{3}$ For instance, contributions by US public pension sponsors fell short of minimum requirements by $\$ 26$ billion in 2017. The minimum requirement is "the amount that would be required to keep pension debt from growing if investment returns had equaled plans’ assumed rates” (PEW 2019: 2).
} 
estimated that implicit global government obligations due to public sector pension promises amounted to \$34 trillion, or double the size of explicit government debt. Matters are likely much worse now (Comtois 2020).

Defined contribution (DC) plans are the main alternative to DB plans. In these, what is specified is the amount to be contributed to a retirement account (often as a percent of payroll), frequently matched by an employer contribution. Account assets are invested as directed by employees in U.S. 401(k) plans (and sometimes, by employers too), while in other cases governments select the asset mix (e.g., Singapore’s Provident Fund). Workers who contribute steadily and invest well can anticipate retirement benefits paid as a lifelong annuity (income for life), a lump sum, or according to a phased withdrawal pattern (as in Chile). Of the total \$47 trillion in global pension assets in 2019, it was estimated that DC plans held over half the total assets under management, surpassing global DB assets (WTW 2020).

DC plans differ from DB plans in that, as long as required employee and employer contributions are deposited as due in the accounts, plan assets by definition are equal to what is owed to participants. Accordingly, employers bear no underfunding risk. DC plans also offer employees the opportunity to hold lower-cost investment funds than many could access on their own, and their accounts may be portable from one firm to another when workers change jobs. Nevertheless, DC plans also transfer investment risk to employees’ shoulders, as these plans generally do not guarantee any particular benefit level in retirement (Mitchell et al., 2011). Given widespread global financial illiteracy as well as substantial consumer ambiguity about investments (Lusardi and Mitchell 2014; Dimmock et al. 2016), it is difficult to expect that most people can make well-considered account investment decisions. Accordingly, many private and public plan sponsors have adopted so-called Target Date Funds (TDFs) as the default investments into which 
workers are automatically enrolled on joining their plans. These include offerings with portfolio allocations described in terms of an expected year of retirement (Mitchell and Utkus 2020). DC plan participants also bear longevity risk, perhaps running out of assets if they draw down their accounts too quickly. This is a concern in many countries, including the U.S. and Australia, where DC plans have traditionally not provided retirees a simple way to convert retirement assets into insured income payouts. This problem is a growing concern, as cognitive aging problems increasingly beset the world’s aging population (c.f., Santucci 2019; Mazzona and Peracchi, 2018; Korniotis and Kumar 2011).

\section{B. Other Challenges to Global Retirement Systems}

Policymakers had also identified several other factors challenging retirement saving and retirement security before the pandemic sprang into view. One deep concern in many developing countries has been low rates of retirement system coverage. This arises when a substantial portion of the working population pays into no retirement system; reasons for this include labor market informality (often driven by low wages), distrust in government and/or financial institutions, lack of financial literacy, high discount rates, high fees, and/or the existence of selfhelp groups providing a modicum of community risk sharing (OECD nd). For instance, fewer than one-third of China's total workforce currently pays into a retirement system of any kind (Jackson et al. 2019).

Low coverage rates have also spread due to the growth of non-standard or 'gig work' for part-time, temporary, and self-employed persons who have no employer offering pension saving arrangements. This is especially problematic for low-paid workers (OECD 2019). Despite a recognition of this problem, efforts to extend coverage by mandating contributions are often politically unpopular, including in Chile where the government sought (rather controversially) to 
require contributions to the national DC plan by self-employed workers who were not previously covered (Joubert and Todd, 2011). Yet Israel was able to mandate pension contributions totaing 20\% of pay for the self-employed, in 2011 (Wrobel 2009). Another consideration is that sometimes, efforts to automatically enroll noncovered low-wage workers into retirement plans results in them incurring additional debt (Beshears et al. 2019; Andersen and Hansen, 2020). This offsets some of the positive effects of pension autoenrollment (Benartzi and Thaler 2004). Finally, high unemployment rates and extended period of joblessness can reduce pension payouts when old-age benefits paid by the government depend on the number of years that workers contribute to the funds.

A different concern regarding retirement systems around the world has been that pension system early retirement rules, generous benefits, and high taxes on earnings have induced people to retire earlier than they might have otherwise (OECD 2019). Moreover, such practices fly in the face of research showing that older workers in as policy recommendations many developed countries have the "health capacity" to work several more years (Coile et al. 2017). A related behavioral finding pertains to how retirement benefits are “framed.” For instance, Brown et al (2016) showed that people would elect to take their benefits more than one year earlier, when presented with a breakeven calculation framing the decision to take Social Security benefits as a risky bet on their own length of life, versus a presentation emphasizing the longevity insurance aspects of the choice. ${ }^{4}$

These design problems have prompted half of the OECD nations to implement so-called "parametric pension system reforms" in the last decade, by boosting contribution rates, indexing retirement ages to longevity, lowering benefits, expanding mandatory pension coverage, and

\footnotetext{
${ }^{4}$ Moreover, framing the claiming decision in terms of gains generated later claiming patterns, compared to a presentation of losses incurred by claiming benefits early.
} 
changing tax rules for retirees. The European Union also recently rolled out a new individual account-based DC plan covering workers across the EU, known as the Pan-European Pension Program (PEPP), seeking to enhance retirement saving as well as labor mobility across the region. Nevertheless, as the OECD (2019:11) noted, such reforms can also be undone, and “[b]acktracking on reforms that address long-term needs may leave pension systems less resilient to economic shocks in the future and unprepared to face population ageing.”5

Table 1 summarizes the world pension sustainability rankings developed by Melbourne Mercer (2019), based on that group’s assessment of each retirement system's adequacy, sustainability, and integrity in 2019. Denmark and the Netherlands ranked as "first class systems" receiving a mark of A, while other European countries and Singapore clustered around a grade of B; the US and France received a mediocre mark of C+. Scoring a barely passing mark of D were China, Korea, Japan, India, the Philippines, and Mexico, each of which was assessed as having major weaknesses casting pension efficacy and sustainability in doubt.

\section{Table 1 here}

We would be remiss if we failed to mention another grave concern confronting capitalized (funded) pensions around the world: persistently low investment returns. Even before the COVID-19 crash, low interest rates had become a long-term reality around the world for several years (Bernanke 2015; Lewin, 2016; Zeng, 2017). This reality has contributed to severe DB underfunding, particularly when actual returns fall far below those assumed when computing contribution obligations. DC plans, which are now the norm in many countries, face even more complex challenges, since they do not have explicit funding targets yet they also suffer when capital markets underperform. Using a life cycle dynamic optimization model, Horneff et al.

\footnotetext{
${ }^{5}$ For instance French President Macron recently concluded that it was necessary to withdraw his recommendation to raise the normal retirement age from 62 to 64 (Nossiter 2020).
} 
(2019b) showed that, in a low interest rate environment, DC plan participants tend to save less, hold fewer retirement assets in their employer-provided pensions, and claim their retirement benefits later, compared to the "old normal” state of affairs.

In sum, even before the coronavirus emerged, personal and pension savings systems around the world were actually facing deep challenges.

\section{How the COVID-19 Pandemic Affected Retirement Systems}

The COVID-19 virus emerged in Wuhan, China in the late fall of 2019, and it was declared to be a global public health emergency at the end of January 2020 (Mogaji 2020). A dramatic sign of the pandemic's impact on retirement systems became rapidly evident with the U.S. equity market crash starting February 24, 2020, followed by several aftershocks felt throughout global financial markets. In March of 2020, global stock markets lost around \$20 trillion (Slok 2020).

\section{Some Macroeconomic Changes}

In view of the massive dislocations the virus has generated around the world, and the lack of widespread testing as well as the nonexistence of effective and reliable treatments and vaccines, it is difficult to forecast when a "new normal" might emerge. ${ }^{6}$ In the larger macroeconomic context, it has been predicted that the COVID19 epidemic will depress the real (risk-free) rate of return for decades, and it will exert a drag on capital markets generally. Based on historical evidence of past European pandemics, Jorda et al. (2020: np) concluded that the "after-effects of the pandemics persist for about 40 years, with real rates of return substantially depressed.” Offsetting this pessimistic outcome somewhat is the authors' prediction that real wage rates will rise over the same period. This could help offset the massive drop in the employment to population

\footnotetext{
${ }^{6}$ For some interesting educated forecasts see Baker et al. (2020a, b, c)
} 
ratio from January 2020 to April 2020: for instance in the U.S., it fell from 60\% down to 52\%. Coibion et al. (2020:4) indicated this was "larger than the entire decline in the employment to population ratio experienced during the Great Recession.” Concurrently, federal debt levels are heading up rapidly in the EU and the US, giving rise to new concerns about fiscal sustainability (Slok 2020).

\section{Retirement Plan Impacts}

Meanwhile, what can we say about the near term and longer run impacts on retirement plans? On the DB front, early evidence implies far more worrisome levels of underfunding than before. Yet because many DB plans are allowed to "smooth" their funding patterns over several years, it will take time before the full impact of their investment losses is fully recognized. Even the Dutch pension plans, previously among the best funded in the world, fell from a $105 \%$ funding rate before the COVID-19 shock, to below 70\%. This is likely to require important benefit cuts under that system's rules (van Alfen 2020). U.S. state and local pensions are also suffering, where plan funding has fallen from an estimated 52\% to 37\%. Even larger drops are foreseen for Connecticut (now having a 28\% forecasted funding rate), Kentucky (25\%), New Jersey (24\%), and Illinois (20\%), leaving only a few years of assets with which to pay benefits (Brown 2020). U.S. corporate DB plans faced $\$ 619$ billion in underfunding as of March 2020, up from \$329 billion at the end of 2019 (Morgan Stanley 2020). Moreover, the SECURE Act of 2020 permitted corporate DB plans to delay their 2020 contributions until 2021, to help plan sponsors conserve cash during the worst of the COVID-19 shock (Bradford 2020b). This will not improve DB plan funding levels, to say the least.

National and occupational retirement systems, many of which are DB plans, are also feeling the pain as payrolls and government tax revenue contract. Moreover, rising numbers of 
jobless workers are likely to elect early retirement payments in order to survive after unemployment benefits run out. Unfortunately, it is difficult to clearly assess how the COVID-19 shock has altered funding ratios across global DB plans, since as the OECD (2019: 222) notes, "Funding levels are calculated using national (regulatory) valuation methodologies of liabilities and hence cannot be compared across countries." ${ }^{\prime 7}$ Nevertheless, it is already clear that such systems will require additional funding in order to make good on retiree benefit promises. For instance, to cover promised pension benefits, Uruguay's pensions will require state support that will rise from just over one percent of GDP in 2035, to close to three percent by 2075 (FIAP 2020). The US Social Security system had already been projected to be able to pay only about threequarters of scheduled benefits within a dozen years, reflective of underfunding estimated at \$53 trillion in present value (in perpetuity; Social Security Trustees 2020). In the wake of the pandemic, however, some estimate that the date of fund depletion may be now be 2029, far sooner than projected (Brandus 2020; Gladstone and Akabas 2020; LaPier 2020).

Defined contribution plans have also experienced the market pounding of 2020, along with the ensuing joblessness and economic pain felt around the world. Some politicians have seized the opportunity to take over funded plan assets. In Colombia, for example, the money is being used for political purposes, while the government is promising to pay retiree benefits at a later date (Barria 2020). Additionally, several countries have permitted plan participants to withdraw assets from their retirement and unemployment funds to ease financial shortfalls during the COVID-19 period. For instance, Australia has allowed withdrawals of up to A $\$ 20,000$ from workers' retirement accounts, and Congressional groups in Chile and Peru have proposed giving workers early access to a portion of their accumulated funds intended for retirement (FIAP 2020). The 2019

\footnotetext{
${ }^{7}$ Gold (2015) has written extensively on this point.
} 
U.S. CARES Act similarly allows DC plan participants adversely affected by the pandemic to withdraw up to $10 \%$ or $\$ 100,000$ of their retirement assets without penalty (though income tax must be paid, spread over up to three years; Anzalone 2020). In addition, conditions have been loosened for workers to take DC plan loans. One estimate projects that half of US workers have already dipped or plan to dip into their retirement funds under this provision (Singh 2020).

Whether and when such asset withdrawals are consistent with sensible economic behavior is controversial. For instance, some advisors urge people not to spend out of their retirement accounts when young (Leonhardt 2020), while others note that taking a plan withdrawal might enable workers to delay the age at which they claim their Social Security benefits (Ebeling 2020), thereby boosting eventual benefits. Another post-COVID-19 policy change important in the U.S. DC plan context is that numerous plan sponsors have reduced or suspended their matching contributions to workers' accounts, seeking to maintain their cash cushions. As many as 200,000 firms may also terminate their DC plans completely (Wilcox Volz 2020). Such cuts, in addition to the loss of employee health insurance coverage due to joblessness, will exacerbate the negative impact of the COVID-19 shock though they may be necessary for firm survival.

A related topic pertains to whether DC participants will alter their investment portfolios in the wake of the COVID-19 market shock. Bu et al. (2020) analyzed changes in risk preferences in the region of China first subject to the pandemic, finding that survey respondents displayed far more risk aversion in February of 2020, compared to before the quarantine went into effect in October of 2019. ${ }^{8}$ In the US, industry reports have indicated that some near-retirees moved money out of their Target Date Funds in the first quarter of 2020, though 99.3 percent of the employees studied made no change (Hallez 2020). Thus far, therefore, retirement plan participant behavior in

\footnotetext{
${ }^{8}$ An Italian study (Beine et al. 2020) also found that people became more risk averse after natural disasters.
} 
developed countries at present suggests little participant investment response, similar to what was seen during the GFC (Tang et al. 2012). Nevertheless, some governments are encouraging changes in DC investment portfolios. For example, the Australian Prime Minister, Scott Morrison, has recommended that retirement savers "bail out" companies impacted by the deep recession afflicting the economy (Burgess 2020). Chile’s Central Bank has boosted limits on how much the national mandatory pension system can invest in alternatives, to "help to diversify investments and improve risk/return prospects” (Baker 2020d: np). For these reasons, one cannot discount policymaker efforts to alter participants' retirement portfolios as the "new normal" emerges.

A topic becoming increasingly salient in the context of the global pandemic is how population subgroups are being differentially affected (e.g., by sex, age, ethnicity/race, educational level, and the like). Alon et al. (2020) note that “conventional” recessions have hurt men's employment more than women's; by contrast, in the present environment, it appears that women, the less-educated, and lower-paid service sector employees are bearing the brunt of both job loss and closure of child care facilities. ${ }^{9}$ Lower-paid workers are especially unlikely to have paid leave or healthcare insurance from their employers, leaving them more likely to need to work while being less well protected. Moreover, in the U.S., women hold one of every three jobs categorized as "essential" during the current pandemic, meaning that these workers must remain on the job as they are needed for health and safety reasons (Robertson and Gebeloff 2020). In poor countries, the problems are even greater, particularly in slums, refugee camps, and densely populated urban areas where sanitation and healthcare were inadequate prior to the pandemic. Moreover, since women comprise 70 percent of healthcare workers around the world and are also responsible for much domestic work, many are having difficulty remaining quarantined (Oxfam 2020). Global

\footnotetext{
${ }^{9}$ They also note that unemployed fathers may take on child care responsibilities which could have a potentially positive impact on household gender equality.
} 
inequality is also expected to spread, since epidemics are more likely to infect and kill, the poor, and survivors are experiencing job loss and pay cuts (Fisher and Bubola 2020). Mandatory lockdowns in India and the Philippines have stranded many workers who lack resources to obtain even basic food supplies (Einhorn et al. 2020).

\section{Retirement Impacts}

Beyond hollowing out DB and DC retirement plans, the COIVD-19 pandemic has also starkly altered peoples' retirement prospects, as workers and retirees begin to recognize their far greater susceptibility to catastrophically expensive health problems. In times past, retirees often relied on the " 4 percent rule" as a heuristic to determine how much they could withdraw from their pension pots to live on. Now the pandemic has spurred some financial advisers to drop this recommendation to 2.4 percent (Wollman Rusoff 2020). In the US, the "cost of retirement," or the amount of money one would need to save in order to generate a payment of $\$ 1$ per year for 25 years has risen by 14 percent, from $\$ 21$ for a target retirement in 2040 in 2019, to almost $\$ 24$ in March 2020 (Figure 2). Importantly, these calculations do not generally make allowance for rising out-of-pocket healthcare costs in retirement (Figure 3).

Figures 2 and 3 here

In the background, both pension schemes and social safety net programs have now realized they face much greater demands on them as the global recession settles in. Prior to the pandemic, the EU already spent over a quarter of its GDP on "social protection” programs, and the crisis is exacerbating these costs massively (The Economist 2014). Gentilini et al. (2020) found that, as of end-March 2020, 84 countries had launched or enhanced a total of 283 social protection and jobs programs around the world in response to the COVID-19 shock, with the vast majority of them 
transfer programs. The as-yet untold cost of these programs will need to be met in the future, but few politicians have begun to think about how to do so effectively (Figure 4).

Figure 4 here

Working longer is likely to be one pathway to survival, if and when the pandemic subsides sufficiently to permit millions to seek employment. The long term job market repercussions are not yet known, but a March 2020 survey of Americans age 55-60 indicated that 44 percent would defer their retirement given the big drop in their retirement portfolios. Of these, 18 percent claimed they would work at least five more years (SimplyWise 2020). When working from home is feasible, such employment will likely be more attractive to people who otherwise would need to commute to work via public transportation. For instance, about one-third of workers in the greater New York City metropolitan area used public transport to get to their jobs prior to the pandemic (Levanon et al. 2020), and a mass return to work would exposing many to high risk of contagion (until a vaccine is available). As a result, forecasters project that there will be continued interest in telecommuting for many occupations (Figure 4). Also several companies have encouraged employees to work from home, and half of the firms surveyed by Willis Towers Watson were subsidizing the costs of remote work (Moran 2020). Yet in the U.S., two-thirds of all jobs cannot be performed at home (Malicdem 2020), and the fraction is far higher in more labor-intensive economies (Figures 5 and 6).

Figures 5 and 6 here

Longer term, older workers are likely to have a more mixed response to the pandemic. On the one hand, some may retire early and claim their pensions if they are old enough to do so, rather than confront what will likely be massive unemployment for some time to come. In so doing, their benefits are likely to be reduced due to early claiming, portending ill for wellbeing at later ages. 
On the other hand, there has been a long-term trend toward "phased" retirement and bridge jobs, where older workers maintain a foot in the labor market without retiring completely (Quinn and Cahill 2017). The popularity of such partial retirement patterns had been rising steadily in the US prior to the pandemic, and as businesses re-open, it is likely that this tendency will grow post COVID-19. The situation is rather different in poor countries such as India, where working conditions have worsened as unemployment has risen: some states now permit firms to require maximum work weeks of 12 hours per day, 72 hours per week, with a widespread relaxation of labor laws (The Economist 2020).

One big unknown is when people will be able to return to work, and what their physical and mental condition will be when that time arises. As yet, there are no proven vaccines to protect the uninfected, testing is woefully inadequate, and as many as half of those who are carriers are asymptomatic (Plater 2020). Further, it is unclear whether those who have survived the disease can become re-infected. And even after recovering from the virus, it appears that many will remain hobbled by heart disease, impaired lung capacity, kidney and liver problems, and mental distress; also, as with some other viruses, there is a chance that the disease may lie dormant in the body, only to reappear years later (Healy 2020). Whether and how resilient global labor markets are remains to be seen, but unless jobs can be found for the billions who have lost them (PPI 2020), the economic impact of the COVID-19 will be felt for years to come.

\section{III.Reforming Pensions Post-Pandemic To Enhance Retirement Security: The Accumulation Phase}


Against this backdrop of substantial economic and political uncertainty, it is important to identify and facilitate the kinds of pension reforms that can enhance workers' ability to save and invest for retirement. (In the next section we focus on the decumulation phase).

One lesson we have learned is that tying workers’ pensions (and in some countries, health insurance) to an employment relationship is quite risky when firms go out of business and worker mobility results. Therefore, in the wake of the pandemic, retirement and health insurance coverage are likely to be delinked from employer-provided plans in many countries, instead of continuing what was once termed "industrial feudalism" under which workers were discouraged from leaving their firms for fear of losing their benefits (Ross 1958; Mitchell 1983). The U.S. SECURE Act of 2019 now allows private sector employers to establish and operate multiple-employer pension plans; this had been infeasible in the past due to rules requiring all sponsor firms to be in the same industry (O’Brien 2019). The new law also requires employers to offer part-time and part-year workers access to the firms' DC plans, which could potentially benefit workers as the labor market recovers.

A different approach to expand coverage in the U.S. has been led by six states (Oregon, California, Connecticut, Illinois, Maryland, and New Jersey) which have launched state-based DC plans that employers must make available to workers if they do not offer a retirement plan (Belbase et al. 2020). In Oregon, the earliest implementer, the program was succeeding in covering lowerpaid workers at small firms who deposited an average of $\$ 110$ per month, or about $5 \%$ of their pay (Chalmers et al. 2019). Each year thereafter, the contribution rate is to be auto-escalated by one percentage point until a contribution cap of $10 \%$ is reached. The first $\$ 1,000$ of each worker's savings is held in a money market fund, and any contributions above that level will be deposited into an age-appropriate target date fund. One important feature of the OregonSaves plan is that 
employee accounts are managed and invested at the state level, so workers who change jobs can continue to contribute to their centrally-held accounts (thus far, as long as they remain in-state).

Other countries, including many in Europe, have occupational-based pensions, so that as long as a worker remains in a given occupation, his account continues to grow. Yet the labor force of the future is likely to be even more mobile than in the past, implying that workers will need greater flexibility to retain their pension plans as they seek employment across state, and national, borders. The Pan-European Pension Plan (PEPP) outlined by the European Commission (2019) was intended to offer workers across the European Union an additional option (in addition to state and occupational pensions) to save for retirement. Unfortunately, it now appears that PEPP will prove to be difficult to market, as the EU regulator is requiring a money-back guarantee, capping administrative fees, and requiring the plans to pay very high long-term risk-free rates (of 3.75\% in 2020; Pielichata 2020; Horneff et al. 2019a).

The financial disruption due to the pandemic is also likely to hasten the demise of the remaining traditional DB plans around the world, unless they receive substantial financial transfers to bail them out or are dramatically altered to survive in different form. For instance, several U.S. states including Illinois have requested federal help to enable them to continue paying retiree benefits (Bauer 2020). Indeed the specter of state bankruptcy has already emerged as a potential result of several U.S. states being unable to contribute enough to maintain their pension plans (Bradford 2020a). How long the European Central Bank can continue to cover member country debt is also coming into question (Fairless and Kownsmann 2020). Developing countries face the most difficult prospects, as they confront enormous medical care costs, plummeting tax revenue, an inability to issue bonds, and food insecurity. In fact, the International Monetary Fund has 
estimated that at least $\$ 2.5$ trillion will be required to help them confront the pandemic-generated unemployment, resulting poverty, and reconstruction needs (Gelpern et al. 2020)

Several new models for pensions have been introduced in recent years that may spread in the future. Focusing first on DB plans, Rappaport and Peterson (2016) summarize several plan features that alter how risks are shared across workers and employers. As one example, a hybrid plan can include a commitment to change benefits or discontinue benefit cost-of-living adjustments if funding levels fall. A hybrid plan could alternatively raise contributions if the plan's financial position declined below some threshold. In some cases, longevity risk in DB plans may be outsourced to insurers. In other cases, funding risk has been backstopped by government entities including the UK's Pension Protection Fund and the US Pension Benefit Guaranty Corporation. Nevertheless, these government entities are themselves facing financial troubles, particularly in the U.S., leading one to conclude that this approach to risk transfer was not very successful. The Netherlands has implemented DB-type “defined ambition” plans, where instead of guaranteeing a benefit, the pension seeks to 'target' promised benefits at some percent (e.g. 75\%) of careeraverage pay. Actual payouts depend on the pension plan’s level of funding (Bovenberg et al. 2016). Whether this model will survive the pandemic is unclear, particularly given $70 \%$ funding levels the plans appear to have at present (van Alfen 2020) and forecasts of long-term poor capital market performance (Jorda et al. 2020; Horneff et al. 2018).

In view of the long-term decline of DB plans around the world, DC plans are likely to remain the engine of growth in the future, and several features are likely to find increasing favor in a post-COVID-19 world. There has already been widespread adoption of automatic enrollment of new workers into DC plans, as well as annual auto-escalation of contribution rates (Benarzti 
and Thaler 2004; OECD 2015). Some 19\% of states in the U.S. have now begun to offer DC plans, as well, sometimes replacing old DB plans (Aubry and Wandrei 2020).

A key question in such circumstances is how plan sponsors and their employees will want to rethink plan contribution rates. If real returns remain low for years, it will be critical for workers to save far more than they did in the past to cover their golden years. For instance, Poterba (2014) has predicted that contribution rates must rise to $33-48 \%$ of pay, in order to support a nominal annuity stream covering half of workers' pre-retirement incomes when real returns are $2 \%$ and the saving period lasts only 20 years. A 30-year contribution period still requires saving $15-16 \%$ of pay to generate the same target, and saving rates must rise higher still if the goal is to generate a payout stream that (more or less) keeps pace with inflation (Table 2).

\section{Table 2 here}

A related issue is how DC plan participants will chose to allocate their retirement assets. Assets in U.S. target date funds (TDFs) grew from \$5B in 2000 to over \$730 B in 2018, in part because regulation permitted these to be the default investments in workers' retirement accounts. Additionally, many employers have chosen these as the default fund offering (Mitchell and Utkus 2020). TDFs are usually identified with an anticipated retirement year, providing plan participants with implicit advice about which fund to hold (e.g., the 2040 fund would be deemed appropriate for someone intending to retire in that year; Bodie and Crane, 2007). Moreover, each TDF has a distinct equity glide path, which reduces portfolio risk as participants near their retirement year. Investment choices are handled by professional portfolio managers who rebalance as necessary along the glide path. In other countries such as Chile and Mexico, the governments have instituted glide paths which depend on investor age, moving participants into less risky funds as they near retirement (Schlecter et al. 2019). Research on U.S. target date funds in the 401(k) plan context 
has shown that pure investors in a low-cost target date series may earn returns that are sufficient to boost retirement wealth by as much as 50 percent over a 30-year savings horizon, compared to their non-TDF counterparts (Mitchell and Utkus 2020). Additionally, the advent of robo-advice is beginning to give workers inexpensive online guidance on how to allocate their savings, and many new FinTech programs are targeting peoples’ wallets (Agnew and Mitchell 2019).

In the wake of COVID-19, efforts to build better retirement plans will likely clash with governments' efforts to raise taxes on pension savings, as seek to recoup the massive fiscal expenditures prompted by the pandemic. As a result, there may be substantial change in how retirement saving plans are taxed. Currently, many countries exempt both pension contributions and investment earnings on the assets (E), and retirees' benefits are subject to tax (T); hence the acronym EET. The opposite approach would be to tax the contributions, and then to exempt investment earnings and benefit payouts (EET; Whitehouse 2005). In a simple world, these two approaches provide the same revenue to the government in present value. In reality, however, the latter approach generates more tax revenue in the immediate future, which may be attractive to governments facing enormous current obligations. ${ }^{10}$ In the real world, of course, there are many nonlinearities and kinks in both tax and benefit schedules, so moving from an EET world to a TEE world can generate important differences in the incentives to work and save. An analysis by Horneff et al. (2019b) found that, in the U.S. context, moving to a TEE system would lead to a reduction in work hours, later retirement ages, greater consumption inequality in retirement, and lower government revenues. Hence such a policy change would not solve government shortfalls by any means.

\footnotetext{
${ }^{10}$ Other combinations of tax regimes may also be found; see Whitehouse (2005).
} 
Delayed retirement is likely to become increasingly necessary post-pandemic, given low expected returns, pension shortfalls, and the rising longevity of the older population. Accordingly, retirement saving plans that permit and even encourage continued work, allow for worker mobility across firms and countries, and offer low-cost investment advice, are likely to help enhance old age security.

\section{IV.Reforming Pensions Post-Pandemic to Enhance Retirement Security: The Payout Phase}

Next we turn to a discussion of the period during which pensions can help retirees better manage their savings during the payout phase. Yet designing customized withdrawal plans for older persons is highly complex, perhaps even more so than designing the accumulation phase, since consumers need to understand and account for the risk of outliving their assets, inflation, capital market fluctuations, health risk, the role of housing equity, and how company-based pension payouts interact with social security systems and taxes. Moreover, couples tend to have even more complicated challenges, such as when both have workplace based pensions, are of different ages, have children for whom they must make provision, and must decide on life and health insurance plans as well. For this reason, the robo-advisors mentioned above have much farther to go to integrate the complexity of real-world retirement payout modelling (Agnew and Mitchell 2019).

One topic commanding recent attention is how to help DC plan savers convert their retirement nest eggs into lifelong annuities protecting them from outliving their savings. Some countries have explicitly required that annuities be embedded into the payout phase, such as the German Riester plans (Kaschützke and Maurer 2011). Singapore also requires that all retirees covered by its Central Provident Fund (CPF) use a portion of their retirement savings to purchase 
a deferred annuity. Chile mandates either annuitization or a so-called programmed withdrawal process regulating how quickly money can be withdrawn in retirement (Berstein et al. 2015). In Israel, Hurwitz and Sade (2020) found a high level of adherence to minimum mandatory annuitization. Horneff et al. (2020) showed that defaulting only 10\% of DC plan savers' assets into a deferred annuity payable from age 80 (or 85 ) can substantially enhance retiree welfare, as long as the assets accumulated by age 65 exceed a relatively low threshold. Nevertheless, where annuitization has not been integrated into DC plans from the outset, it has proven difficult to add that requirement after the fact, as in Australia.

It is also worth noting that many different types of annuities exist, and the diversity around these financial instruments generates complexity and consumer misunderstanding about the products. For instance, consumers' cognitive abilities and financial literacy strongly influence their willingness to purchase annuities, partly because these are decisions people make rarely, and partly because people can be "steered" toward or away from lifetime annuity products depending on how the products are presented (or "framed"; Brown et al. 2017, forthcoming). Interest in tontines is also growing: these are products purchased by a set pool of investors and held over time. In simplest form, when someone in the pool dies, his or her assets are divided among the remaining survivors and the last survivor takes all (Milevsky 2015). Legal tontines are now operating in South Africa and France, and other countries have expressed interest as well (Fullmer, 2019). In the U.S., participating annuities share some important similarities, in that sellers of the products bear no mortality risk and hence can pay out more than traditional fixed annuities (Maurer et al. 2013, 2016a, b). Each of these products offers promise for retirees seeking to protect against longevity risk. Nevertheless, with interest rates at or below zero, annuities have become relatively expensive for purchasers (Arends 2020). 
In sum, post COVID-19, it will be challenging but critical to provide more retirees access to low-cost annuities and high-quality but low-cost investment advice. Additional research and product development will be required, to make the retirement decumulation process easier for retirees to manage. Moreover, different delivery systems for financial advice will likely be appealing to different subsets of consumers. For instance Ben-David and Sade (2018) found that younger adults prefer algorithmic over human advice, whereas the middle-aged favor a hybrid model. They also reported that men were more likely to adopt and were willing to pay more for financial advice than women.

\section{Potential Roles for Policymakers}

Though the ultimate impacts of the coronavirus are not known, demographers and epidemiologists are beginning to assess how the disease is likely to affect overall population patterns, and the results are as yet not clear. For example, Goldstein and Lee (2020) estimated that, if 1 million excess U.S. deaths were attributed to COVID-19, this would reduce the population's years of life remaining by $1 / 1000$, below the excess mortality attributable to the Spanish flu but similar to the impact of the HIV and opioid crises. Nevertheless, the authors felt that the risk for older people was far higher, noting that a "78 year-old during the epidemic would be exposed to the risk faced by an 80 year-old in normal times” (p. 6). By contrast, Cairns et al. (2020) reported that the impact of COVID-19 on mortality rates of the surviving population in the UK will likely to be modest, in that survivors' life expectancies are unlikely to differ much from prior to the pandemic. In other words, the two century-long trend toward population aging is likely to continue and maybe even rise more, insofar as the older population in some countries has apparently attained a "mortality plateau” (Figure 7). 
Figure 7 here

Accordingly, even after the pandemic is brought under control, the world will continue to age, giving even greater urgency to reform old-age systems to help support the aging population. Policymakers can play a critically important role in this process, as they move to reform retirement systems while setting in motion broader plans to emerge from the pandemic.

\section{Retirement System Design Efforts}

One change that policymakers could consider to enhance retirement planning would be to generate and make available better quality and more granular data about mortality and morbidity patterns. These could help insurers seeking to price longevity risk around the world (Mitchell et al. 2006).

Second, evaluating retirement security is likely to require the development of a consistent and economically coherent set of guidelines for measuring and forecasting social security and pension assets and liabilities, as well as the assessment of long term care needs for the aging population (Hurd et al. 2013).

Third, policymakers are likely to want to encourage delayed retirement, delicately where possible. For instance, Maurer et al. (forthcoming) found that older individuals would claim their social security benefits later and work longer if they were allowed to receive a partial lump sum when they finally claimed, in exchange for the deferral. In view of evidence that longer lifespans allow people to work longer and healthier (Fitzpatrick and Moore 2017), and that jobs are less physically demanding now than in the past (at least in developed economies), work at older ages is increasingly feasible. Nevertheless, many firms and nations still impose mandatory retirement policies discouraging employers from hiring older individuals and giving middle-aged workers few incentives to invest in their human capital. Additionally, it will be important for plan designers 
to revisit the practice of setting relatively young retirement ages for benefit eligibility. Such rules are often interpreted by middle-aged people as recommendations to leave the workforce young, depreciating human productivity and raising the cost of old age pensions financed by the young.

Fourth, a potentially very useful development could be to de-link the provision of benefits from employment. Thus instead of pensions, healthcare, and insurance programs being offered though the workplace, these could be made available by associations or multiple-employer programs, or indeed workplace platforms. As noted above, this was facilitated in the U.S. by the passage of the 2019 SECURE Act, which now allows firms to band together to offer benefits, thus reducing administrative costs (Tergesen 2019). In this new format, workers would no longer need to remain tied to a single firm, to retain their pensions and health insurance. That Act also gave an invaluable push to annuitization in DC plans, giving firms a safe harbor to adopt a lifetime payout component in their retirement plans. A related development could be a centralized database such as that adopted in Israel which helps mobile workers track their pension accounts as they move across employers (Rosen and Sade 2019).

Fifth, an aging world is likely to need the greater flexibility afforded by the "gig economy," as this sector can offer older people the opportunity to engage in flexible, part-time, and other ondemand work opportunities (AARP 2016; Abraham et al. 2020). The work-from-home trend imposed by the pandemic is also likely to continue after the emergency, as employees decide that they can reduce their commutes, do not need to travel as much, and can be at least as productive in online meetings. Of course, one consideration regarding this trend is the fact that pension, health, and other employee benefits have traditionally not been provided to gig workers, meaning that many older employees needing such coverage could be at a disadvantage (Figure 8). Interestingly, however, the status quo is beginning to change as some firms including Uber now offer 
partnerships helping drivers obtain low-cost health insurance (LaPonsie, 2018). The pandemic has also enhanced the provision of sick leave policies for workers at a national level, previously unavailable in some countries. For instance, the U.S. Families First Coronavirus Response Act of 2020 mandated a temporary period of sick leave due to illness or family responsibilities (Moran 2020). Legislators are also pushing for additional benefits such as workers' compensation and disability payments for workers who have lacked these in the past (Pardes 2020).

Figure 8 here

\section{Broader Efforts}

In the wake of the pandemic, widespread financial education programs could also be extremely beneficial both for older workers and their younger counterparts. With more information, people do a better job planning, saving, and decumulating during retirement, and they could also do better handling complex financial products such as mortgages, loans, and annuities. Indeed, recent research has demonstrated a strong positive effect of financial literacy and financial education on financial behaviors and retirement preparedness (Lusardi and Mitchell, 2014; Kaiser et al. 2020), including reducing peoples' tendency to take on and hold debt at older ages (Lusardi et al. 2013, 2019).

The global pandemic has also revealed very serious cracks in many countries’ social safety net programs, including the unemployment benefits regime, housing and medical care systems for the poor, and food distribution channels (Moffitt 2020). Some countries appear to be managing this problem better than others. For instance, Denmark's government has subsidized $75 \%$ of wages for workers in firms hit by the virus slowdown, and Germany provided loans to firms facing bankruptcy (Wood 2020). By contrast, the patchwork of state-based unemployment insurance, Medicaid, and Food Stamp programs in the U.S. has made it nigh impossible for millions of 
workers to file for payments, and many others have discovered that they are simply ineligible. Informal sector workers in Asia appear to be particularly at risk, as few are covered by social insurance and many live hand-to-mouth (Dabla-Norris and Rhee 2020).

To help fill the holes in safety net programs, some analysts and policymakers have proposed the adoption of a Universal Basic Income (UBI) scheme as a means to provide a floor of government-guaranteed income regardless of age, income, or employment status. Without digging into the details of such a plan, it does appear that in the US, such a program would be extremely expensive: one research team (Hoynes and Rothstein 2019) has noted that it could require financing on the order of twice the cost of current transfer programs. Additionally, it is likely to benefit mainly middle-income childless, nonelderly, nondisabled individuals, at the expense of elderly and poor households. Accordingly more research is needed to understand how to balance the equity and the efficiency implications of UBI schemes in an aging world.

Poor countries are likely to have more difficult challenges to recover in the wake of COVID-19, as recognized by leading international organizations such as the World Bank and the International Monetary Fund. To this end, in March and again in April of 2020, the World Bank approved billions to help India as well as other countries (Stankiewicz 2020). The G20, a group of the globe's richest economies, has also committed to massive assistance for poor countries and to coordinate efforts with other agencies including a moratorium of debt payments (Djankov and Kiechel, 2020). Moreover, the legacy of the pandemic is likely to be a substantial increase in global poverty, likely complicated by a massive negative shock to global food supplies. Voss et al. (2020) explored three scenarios for poverty assuming that there will be a labor productivity shock of $1.4 \%$, a total factor productivity shock causing a 1\% decline in global GDP, or a trade shock boosting costs by $5 \%$. They predict millions more people will fall below the global poverty line, particularly 
in rural populations and in sub-Saharan Africa (see Figure 9). A silver lining may be that air pollution levels have fallen rapidly with the pandemic, which is expected to cut mortality and boost health for the affected populations (Cicala et al. 2020).

Figure 9 here

Until testing and vaccines become widespread, these forecasts could quickly become far worse. In one hopeful sign, the World Bank has brought to market "pandemic bonds" to help spread the risk of epidemics such as the SARS and COVID-19 to capital markets (Durden 2020). Such bonds pay investors a relatively high return as long as no pandemic is triggered, but the principal is used to help afflicted countries in the event that the various triggers are met. The catastrophe or 'cat' bond triggered in March 2020 provided \$196 million to the World Bank which is disbursing it for the intended purpose. Nevertheless, there were concerns about the slow rate that at which the funds were paid out have been criticized (Scism and Hinshaw 2020). Private reinsurers such as AXA Re are also discussing how to establish pandemic insurance with several state governments in India (Acharya 2020). Nevertheless, many property and business interruption insurers have been reluctant to admit liability for the coronavirus-induced halt in business as usual, which will likely require regulators to clarify what exactly what must, and what will not, be compensated (Barker et al. 2020).

\section{Conclusions}

As stated at the outset, retirement savings programs around the world were facing deep challenges even before the COVID-19 pandemic struck. Now many new uncertainties confront retirement plan savers, retirees, and plan sponsors, not the least of which is when and whether the labor market will begin to function normally, when healthcare systems will recover from their 
burdens, and when (if) capital markets will begin to provide savers with positive returns. Moreover, no one is yet certain when the pandemic will end (Yong 2020). Nevertheless, in the future, a lesson provided by this pandemic is that pension saving, healthcare insurance, and financial advice could sensibly be de-linked from employers. Of course global needs will vary, as workers become more mobile, more likely to be found in the "gig" economy, and more diverse in their needs (Figure 10).

Figure 10 here

Pension models for the future will also require new methods to share risk, beginning with enhancing financial literacy in the population, helping people to save more and invest smarter, and to better manage longevity. Plan sponsors can also do more to make pensions more flexible, for instance by linking retirement ages and contributions to funding levels. Policymakers could enhance the decisionmaking environment by providing better data to price insurance products, and by formulating better forecasts and establishing plans to respond to the aging population's needs. Raising retirement ages, incentivizing continued work, and helping people save more are also likely to be part of the solution, though answers will vary across countries. Additionally, strengthening safety net programs is also likely to be critical in helping those who cannot work and lack private insurance. Taken together, these can strengthen not only retirement systems around the globe, but also the economic vitality of our economies more broadly.

\section{References}

AARP. (2016). “The Upside of the On-Demand Economy.” http://bit.ly/2wHx4pa

Abraham, Katharine, Brad Hershbein, and Susan Houseman. (2020). "Contract Work at Older Ages." NBER WP 26612.

Acharya, Namrata. (2020). “AXA Moots Mass Insurance Scheme for Loss of Income During Pandemic Lockdown.” Businessstandard.com, April $19 . \quad$ https://www.businessstandard.com/article/companies/bharti-axa-general-insurance-moots-massinsurance-scheme-for-viruspandemic-120041900240_1.html 
Agnew, Julie and Olivia S. Mitchell. (2019). "How FinTech is Reshaping the Retirement Planning Process.” In J. Agnew and O. S. Mitchell (eds.) The Disruptive Impact of FinTech on Retirement Systems. Oxford, UK: Oxford University Press: 1-12.

Alon, Titan M., Matthias Doepke, Jane Olmstead-Rumsey, and Michèle Tertilt. (2020). "The Impact of COVID-19 on Gender Equality.” NBER Working Paper 26947,

Andersen, Henrik Yde and Niels Hansen. (2020). "Mandatory Pension Savings and Long-run Debt Accumulation: Evidence from Danish Register Data.” https://papers.ssrn.com/sol3/papers.cfm?abstract_id=3547997

Anzalone, Joe. (2020). "Retirement Plan Provisions in the Coronavirus Stimulus Bill.” March 29. RiverAndMercantileSolutions.com https://riverandmercantile.us/solutions/news/retirement-planprovisions-in-the-coronavirus-stimulus-bill/

Arends, Brett. (2020), "Plunging Annuity Rates.” April 9. Marketwatch.com, https://www.marketwatch.com/story/plunging-annuity-rates-a-strategy-for-new-retirees-2020-0408

Aubrey, Jean-Pierre, and Kevin Wandrei. (2020). "Have Localities Shifted Away from Traditional Devined Benefit Plans?” Center for State \& Local Government Excellence Issue Brief, April.

Baker, Scott R., Nicholas Bloom, Steven J. Davis, and Stephen J. Terry. (2020a). "COVID-Induced Economic Uncertainty. “ NBER Working Paper No. 26983

Baker, Scott R., Nicholas Bloom, Steven J. Davis, Kyle J. Kost, Marco C. Sammon, and Tasaneeya Viratyosin. (2020b). “The Unprecedented Stock Market Impact of COVID-19.” NBER WP 26945.

Baker, Scott R., R.A. Farrokhnia, Steffen Meyer, Michaela Pagel, and Constantine Yannelis, (2020d). "How Does Household Spending Respond to an Epidemic? Consumption During the 2020 COVID-19 Pandemic,” NBER Working Paper No. 26949.

Baker, Sophie. (2020d). “Chile’s Central Bank Lifts Alts Limits for Retirement Plans.” April 16. Pensions\&Investments.com. https://www.pionline.com/retirement-plans/chiles-central-bank-liftsalts-limits-retirement-plans.

Barker, Alex, Kate Beioley, and Jane Croft. (2020). "Who Pays The Bill? The Coming Deluge of Pandemic Litigation.” FR.com, May 5. https://www.ft.com/content/48d230ae-8df5-11ea-9e120d4655dbd44f?emailId=5eb285ad40765900046577d9\&segmentId=a8cbd258-1d42-1845-7b8200376a04c08f

Barria, Cecilia. (2020). "Coronavirus en América Latina: Los Países Donde la Gente Saca Dinero de su Fondo de Pensiones y Por Qué Tal Vez No es Buena Idea.” April 23. BBCNews Mundo. https://www.bbc.com/mundo/noticias-52363588

Bauer, Elizabeth. (2020). “And So It Begins: Illinois Is First In Line For State And Local Pension Bailouts.” April 17. Forbes.com. https://www.forbes.com/sites/ebauer/2020/04/17/begun-the-state-and-localpension-bailout-requests-have/\#6c2dbe28294e

Baker, Sophie. (2020). "Chile's Central Bank lifts Alts Limits for Retirement Plans.” April 16. Pensions\&Investments. https://www.pionline.com/retirement-plans/chiles-central-bank-lifts-altslimits-retirement-plans

Beine, Michel, Gary Charness, Arnaud Dupuy, and Majlinda Joxhe. (2020). "Shaking Things Up: On the Stability of Risk and Time Preferences.” CESifo Working Paper No. 8187

Belbase, Anek, Laura D Quinby, and Geoffrey Sanzenbacher, (2020). "Auto-IRA Rollouts Gradually Speeding Up.” Center for Retirement Research report 20-5. Boston College.

Bell, Torsten, and Hannah Slaughter (2020). “Crystal Balls vs Rear-View Mirrors. Resolution Foundation. April 7. https,://www.resolutionfoundation.org/publications/crystal-balls-vs-rear-view-mirrors/

Benartzi, Shlomo and Richard Thaler. (2004). "Save More Tomorrow: Using Behavioral Economics to Increase Employee Savings.” Journal of Political Economy. 112(1): S164-S187.

Ben-David, Daniel, and Orly Sade. (2019). “Robo-Advisor Adoption, Willingness to Pay, and Trust — An Experimental Investigation.” SSRN. https://papers.ssrn.com/sol3/papers.cfm?abstract_id=3361710 
Bernanke, Ben. (2015). Why Are Interest Rates So Low? Brookings Institution Report. March 30. https://www.brookings.edu/blog/ben-bernanke/2015/03/30/why-are-interest-rates-so-low/

Berstein, Solange, Marco Morales, and Alejandro Puente. (2015). "The Role of Longevity Insurance in Latin America: Cases of Chile, Colombia, Mexico and Peru.” In Multi-Pillar Pension Systems: Investing in the Future, Ed. International Federation of Pension Fund Administrators. Santiago, Chile: FIAP, 85-202.

Beshears, John, James J. Choi, David Laibson, Brigitte C. Madrian, and William L. Skimmyhorn. (2019). "Borrowing to Save? The Impact of Automatic Enrollment on Debt." NBER WP 25876.

Bodie, Zvi, and Dwight Crane. (1999). "The Design and Production of New Savings Products.” The Journal of Portfolio Management Winter 25 (2): 77-82.

Bovenberg, A. Lans, Roel Mehlkopf, and Theo E. Nijman. (2016). "The Promise of Defined Ambition Plans: Lessons for the United States.” In Reimagining Pensions: The Next 40 Years. Olivia S. Mitchell and Richard Shea, eds. Oxford: Oxford University Press: 161-173.

Bradford, Hazel (2020a). "McConnell Rules Out Pension Aid for States.” April 22. Pandionline.com. https://www.pionline.com/pension-funds/mcconnell-rules-out-pension-aidstates?CSAuthResp=1587656508936:0:36658:455:24:success:8EA56322EC51BDC7BD11FE58 A4567A01\#cci_r=36658

Bradford, Hazel. (2020b). "PBGC Program Set for Reversal of Fortune.” Pensions and Investments. April 6. https://www.pionline.com/washington/pbgc-program-set-reversal-fortune?utm_source=p-ieditor-s-pick\&utm_medium=email\&utm_campaign=2020041\%E2\%80\%A6

Brandus,Paul. (2020). “Thanks to COVID-19, Social Security's Day of Reckoning May Be Even Closer Than We Thought.” April 18. Marketwatch.com, https://www.marketwatch.com/story/thanks-tocovid-19-social-securitys-day-ofreckoning-may-be-even-closer-than-we-thought-2020-0415?mod=MW_section_top_stories

Brown, Aaron. (2020). "Pension Funds Will Take a Big Coronavirus Hit.” Bloomberg.com. April 1. https://finance.yahoo.com/news/pension-funds-big-coronavirus-hit-100054327.html

Brown, Jeffrey R., Arie Kapteyn, Erzo Luttmer, and Olivia S. Mitchell. (2017). "Cognitive Constraints on Valuing Annuities.” Journal of the European Economic Association. 15(2): 429-462.

Brown, Jeffrey R., Arie Kapteyn, and Olivia S. Mitchell. (2016). "Framing and Claiming: How Information Framing Affects Expected Social Security Claiming Behavior.” Journal of Risk and Insurance. 83(1): 139-162.

Brown, Jeffrey R., Arie Kapteyn, Erzo F.P. Luttmer, Olivia S. Mitchell, and Anya Samek. (forthcoming). "Behavioral Impediments to Valuing Annuities: Evidence on the Effects of Complexity and Choice Bracketing." Review of Economics and Statistics.

Bu, Di, Tobin Hanspal, Yin Liao, and Yong Liu. (2020). "Risk Taking during a Global Crisis: Evidence from Wuhan.” https://papers.ssrn.com/sol3/papers.cfm?abstract_id=3559870

Burgess, Matthew. (2020). “Australia’s Morrison Wants Pensions to Fund Company Bailouts.” April 16. Bloomberg.com. https://www.bloomberg.com/news/articles/2020-04-16/australia-s-morrisonwants-pensions-to-fund-company-bailouts

Cairns, Andrew J.G., David Blake, Amy R. Kessler, and Marsha Kessler. (2020). “The Impact of Covid-19 on Future Higher-Age Mortality.” The Pensions Institute, Cass Business School. ISSN 1367-580X, May.

Chalmers, John, Olivia S. Mitchell, Jonathan Reuter, Geoffrey Sanzenbacher, and Mingli Zhong. (2019). "Auto-enrollment Retirement Plans for the People: Choices and Outcomes in OregonSaves.” 21 ${ }^{\text {st }}$ Annual Social Security Research Conference, Washington D.C. https://mrdrc.isr.umich.edu/publications/conference/pdf/2019RDRC\%20P5\%20Zhong.pdf

Ciancio, Alberto, Fabrice Kämpfen, Iliana Kohler, Daniel Bennett, Wändi Bruine de Bruin, Jill Darling, Arie Kapteyn, Jürgen Maurer, and Hans-Peter Kohler. (2020). "Know Your Epidemic, Know Your Response: COVID-19 in the United States." University of Pennsylvania Population Center Working Paper (PSC/PARC) 2020-44. https://repository.upenn.edu/psc_publications/44. 
Cicala, Steve, Stephen P Holland, Erin T Mansur, Nicholas Z Muller, and Andrew J Yates. (2020), "Expected Health Effects of Reduced Air Pollution from COVID-19 Social Distancing." NBER WP 27135, May.

Citi. (2016). "The Coming Pensions Crisis: Recommendations for Keeping the Global Pensions System Afloat.” CITI GPS https://ir.citi.com/CqVpQhBifberuzZKpfhSN25DVSesdUwJwM61ZTqQKceXp0o/0F4CbFnnA YI1rRjW

Coibion, Olivier, Yoriy Gorodichencko, and Michael Weber. (2020). "Labor Markets During the COVID19 Crisis: A Preliminary View.” University of Chicago Booth Working Paper No. 20-06.

Coile, Courtney C., Kevin Milligan, and David A. Wise. (2017). "Health Capacity to Work at Older Ages: Evidence from the U.S." In Social Security Programs and Retirement Around the World: The Capacity to Work at Older Ages. David A. Wise, ed. Chicago: University of Chicago

Comtois, James. (2020). "Underfunded Public Plans Facing a New Round of Woes.” Pensions and Investments, April 6. https://www.pionline.com/defined-benefit/underfunded-public-plans-facingnew-round-woes?utm_source=p-i-editor-s-pick\&utm_medium=email\&utm_\%E2\%80\%A6

Dabla-Norris, Era, and Changyong Rhee. (2020). “A New Deal for Informal Workers in Asia." IMF.org. https://blogs.imf.org/2020/04/30/a-new-deal-for-informal-workers-inasia/?utm_medium=email\&utm_source=govdelivery 8/8

Djankov, Simeon and Anne-Laure Kiechel. (2020). "The G20 Should Do More to Harness the IMF and World Bank” In How the G20 Can Hasten Recovery from COVID-19, eds M. Obstfeld and A. Posen. PIIE Briefing 20-1. https://www.piie.com/publications/piie-briefings/how-g20-can-hastenrecovery-covid-19

DeNardi, Mariacristina, Eric French and John Bailey Jones. (2011). "Why Do the Elderly Save? The Role of Medical Expenses.” Journal of Political Economy 118(1): 39-75.

Dimmock, Stephen G., Roy Kouwenberg, Olivia S. Mitchell and Kim Peijnenburg. (2016). “Ambiguity Attitudes and Economic Behavior: Results from a US Household Survey." Journal of Financial Economics. 119(3): 559-577.

Dolgin, Elie. (2018). “Longevity Data Hint at No Natural Limit on Lifespan.” June 28. Nature 559. https://www.nature.com/articles/d41586-018-05582-3

Durden, Tyler. (2020). “'Pandemic Bonds' Face Near-Total Loss After Soaring Global Deaths Trigger Risk Transfer.” April 17. ZeroHedge.com. https://www.zerohedge.com/markets/pandemic-bonds-facetotal-loss-after-soaring-global-deathstrigger-risk-transfer

Ebeling, Ashlea. (2020). "Should You Take Social Security Earlier Than Planned If You're Laid Off Due to COVID-19?” $\quad$ Forbes.com. April 15. https://www.forbes.com/sites/ashleaebeling/2020/04/15/should-you-take-social-security-earlierthan-planned-if-youre-laid-off-due-tocovid19/?fbclid=IwAR2UirUXt1HFNUJVcvbGXtRkHL5odyJhDYHWlSAf5wPXjOIlgKGq87Zpzs\#1a896c3d12b3

The Economist. (2014). "Is 75 the New 65? Rising to the Challenge of an Aging Workforce.” February 10. EIU Perspectives, The Economist Intelligence Unit. https://eiuperspectives.economist.com/strategy-leadership/75-new-65/white-paper/75-new-65

The Economist (2020). "Indian States are Rushing to Undo Laws Protecting Workers." May 18. https://www.economist.com/asia/2020/05/18/indian-states-are-rushing-to-undo-lawsprotectingworkers?utm_campaign=the-economisttoday\&utm_medium=newsletter\&utm_source=salesforcemarketing-cloud\&utm_term=2020-0519\&utm_content=article-link-2

Einhorn, Bruce, David Malingha, and Fathiya Dahrul. (2020). "Poorer Countries are Least prepared for Pandemic Lockdowns.” April $2 . \quad$ Bloomberg.com. https://www.bloomberg.com/news/articles/2020-04-02/poorer-countries-are-least-preparedforpandemic-lockdowns 
European Commission. (2019). “Capital Markets Union: Pan-European Personal Pension Product (PEPP) Fact Sheet.” https://ec.europa.eu/commission/presscorner/detail/en/MEMO_19_1993

Fairless, Tom and Patricia Kownsmann. (2020). "Investors Ask How Long ECB Can Absorb Eurozone’s Economic Pain.” April 16. Wall Street Journal. https://www.wsj.com/articles/investors-ask-howlong-ecb-can-absorb-eurozones-economic-pain11587060224 ? $\mathrm{mod}=$ searchresults \&page $=1 \&$ pos $=1$

FIAP. (2020). Progress of the Pension Systems: February March 2020. International Federation of Pension Systems, Report No. 2.

Fisher, Max and Emma Bubola. (2020). “As Coronavirus Deepens Inequality, Inequality Worsens Spread.” March 16. NYT https://www.nytimes.com/2020/03/15/world/europe/coronavirus-inequality.html

Fitzpatrick, Maria D. and Timothy J. Moore (2017). "The Mortality Effects of Retirement: Evidence from Social Security Eligibility at Age 62.” Journal of Public Economics. 157: 121-137

Fullmer, Richard. (2019). Tontines: A Practitioner's Guide to Mortality Pooled Instruments. Charlottesville, Va: CFA Institute Research Foundation

Gelpern, Anna, Sean Hagen, and Adnan Mazarei. (2020). "Debt Standstills Can Help Vulnerable Governments manage the COVID-19 Crisis." April. In How the G20 Can Hasten Recovery from COVID-19, eds M. Obstfeld and A. Pozen. Peterson International Institute for International Economics Briefing 20-1.

Gentilini, Ugo, Mohamed Almenfi and Ian Orton. (2020). "Social Protection and Jobs Responses to COVIDE-19: A Real-Time Review of Country Measures.” World Bank Social Protection Paper. http://www.ugogentilini.net/wp-content/uploads/2020/03/Social-protection-responses-toCOVID19_March27.pdf

Gladstone, Nicko, and Shai Akabas. (2020). "COVID-19 May Deplete Social Security Trust Funds This Decade.” Bipartisan Policy Center Report April. https://bipartisanpolicy.org/blog/covid-19-maydeplete-social-security-trust-funds-this-decade/

Gold, Jeremy. (2015). "Where are the Screaming Actuaries?" Wharton School RetireSecure Blog. https://www.forbes.com/sites/pensionresearchcouncil/2015/11/20/where-are-the-screamingactuaries/\#43aa33d027d8

Goldstein, Joshua R. and Ronald D. Lee. (2020). "Demographic Perspectives on Mortality of Covid-19 and Other Epidemics.” NBER Working Paper No. 27043

Gross, Anna. (2020). "In a Post-COVID world, Employers Will Have to Pay Workers More.” April 17, Moral Money.

Hallez, Emile. (2020). "Near-Retirees Drain TDFs at a Rapid Clip.” April 9. Investment news.com. https://www.investmentnews.com/near-retirees-drain-tdfs-191288?NLID=IN-DailyPulse\&NL_issueDate=2020049\&utm_source=IN-Daily-Pulse2020049\&utm_medium=email\&utm_campaign=investmentnews\&utm_visit=25860 [investmentnews.com]

Healy, Melissa. (2020). "Coronavirus Infection May Cause Lasting Damage Throughout the Body, Doctors Fear.” April 10, LA Times. https://www.latimes.com/science/story/2020-04-10/coronavirusinfection-can-do-lasting-damageto-the-heart-liver.

Horneff, Vanya, Daniel Liebler, Raimond Maurer, and Olivia S. Mitchell. (2019a). "Implications of MoneyBack Guarantees for Individual Retirement Accounts: Protection Then and Now.” NBER WP w26406.

Horneff, Vanya, Raimond Maurer, and Olivia S. Mitchell. (2018). "How Low Returns Alter Optimal Life Cycle Saving, Investment, and Retirement Behavior.” In How Persistent Low Returns Will Shape Saving and Retirement, eds. Robert Clark, Raimond Maurer, and Olivia S. Mitchell. Oxford: Oxford University Press: 119-131.

Horneff, Vanya, Raimond Maurer, and Olivia S. Mitchell. (2019b). “How Would 401(k) 'Rothification’ Alter Saving, Retirement Security, and Inequality?” NBER WP 26437. 
Horneff, Vanya, Raimond Maurer, Olivia S. Mitchell, and Ralph Rogalla. (2015). “Optimal Life Cycle Portfolio Choice with Variable Annuities Offering Liquidity and Investment Downside Protection.” Insurance: Mathematics and Economics. 63: 91-107.

Horneff, Vanya, Raimond Maurer and Olivia S. Mitchell. (2020). "Putting the Pension Back in 401(k) Plans: Optimal Retirement Plan Design with Longevity Income Annuities.” Journal of Banking and Finance. 114doi.org/10.1016/j.jbankfin.2020.105783

Hoynes, Hilary and Jesse Rothstein. (2019), "Universal Basic Income in the United States and Advanced Countries.” Annual Review of Economics. 11: 929-58.

Hurd, Michael, Paco Martorell, Adeline Delavande, Kathleen J. Mullen, and Kenneth M. Langa. (2013). "Monetary Costs of Dementia in the United States." New England Journal of Medicine. 368: 132634.

Hurwitz, Abigail, and Orly Sade. (2020). "Unintended consequences of Minimum Annuity Laws: An Experimental Study.” Journal of Economic Behavior and Organization. 169: 208-222.

Jackson, Richard, Keisuke Nakasima, and Neil Howe. (2019). “China’s Long March to Retirement Reform: The Graying of the Middle Kingdom Revisited.” Center for Strategic and International Studies. Washington, D.C.: CSIS.

Jordà, Òscar, Sanjay R. Singh, and Alan M. Taylor. (2020). "Longer-run Economic Consequences of Pandemics.” NBER Working Paper No. 26934

Joubert, Clement and Petra Todd. (2011). “Expanding Pension Coverage: A Dynamic Analysis of Chile’s Pension Reform. https://economics.uchicago.edu/sites/economics.uchicago.edu/files/uploads/PDF/Todd\%20Petra \%20\%20Expanding\%20Pension\%20Coverage.pdf

Kaiser, Tim, Annamaria Lusardi, Lukas Menkhoff, and Carly J. Urban. (2020). "Financial Education Affects Financial Knowledge and Downstream Behaviors.” NBER WP 27057.

Kaschützke, Barbara, and Raimond Maurer (2011). "The Private Life Annuity Market in Germany: Products and Money’s Worth Ratios.” In Securing Lifelong Retirement Income, Eds. Olivia S. Mitchell, John Piggott, and Noriyuyki Takayama. Oxford University Press: 131-158.

Korniotis, George M. and Alok Kumar. (2011). “Do Older Investors Make Better Investors?” Review of Economics and Statistics. 93(1): 244-265

LaPonsie, Maryalene. (2018), “5 Companies that Offer Benefits to Gig Workers.” August 23. USNews.com. https://money.usnews.com/careers/salaries-and-benefits/articles/2018-08-23/5-companiesthatoffer-benefits-to-gig-workers

Leonhardt, Megan. (2020). “Americans Will Soon Be Able to Take Penalty-free Withdrawals from Their 401(k)s, But Experts Say Think Twice about Using Retirement Savings.” March 27. CNBC.com. https://www.cnbc.com/2020/03/26/you-can-now-make-penalty-free-withdrawals-fromretirement-savings.html

Levanon, Gad, Frank Steemers, and Elizabeth Crofoot. (2020). "If Staying Home Comes to Stay: The Rise of Telework and the Decline of City Centers." Conference Board. Blog. 15 April. https://www.conference-board.org/blog/labor-markets/Telework

Lusardi, Annamaria and Olivia S. Mitchell, eds. (forthcoming). Debt in an Aging Economy. Oxford, UK: Oxford University Press.

Lusardi, Annamaria and Olivia S. Mitchell. (2014). “The Economic Importance of Financial Literacy: Theory and Evidence.” Journal of Economic Literature. 52(1): 5-44.

Lusardi, Annamaria, Olivia S. Mitchell, and Vilsa Curto. (2013). "Financial Literacy and Financial Sophistication among Older Americans.” Journal of Pension Economics and Finance. 13: 347366.

Lusardi, Annamaria, Olivia S. Mitchell, and Noemi Oggero. (2019). "Debt and Financial Vulnerability on the Verge of Retirement." Journal of Money, Credit, and Banking. Online https://doi.org/10.1111/jmcb.12671 
Malicdem, Darwin. (2020). “Only 34\% of People Can Work From Home In US Amid COVID-19 Pandemic.” MedicalDaily.com https://www.medicaldaily.com/only-34-people-can-work-homeus-amid-covid-19-pandemic-451575

Maurer, Raimond, Olivia S. Mitchell, Ralph Rogalla, and Tatjana Schimetschek. (forthcoming). "Optimal Social Security Claiming Behavior under Lump Sum Incentives: Theory and Evidence.” Journal of Risk and Insurance.

Maurer, Raimond, Olivia S. Mitchell, Ralph Rogalla, and Ivonne Siegelin. (2016a). “Accounting-based Asset Return Smoothing in Participating Life Annuities: Implications for Annuitants, Insurers, and Policymakers.” In Olivia S. Mitchell, Raimond Maurer, and J. Michael Orszag, eds. Retirement System Risk Management: Implications of the New Regulatory Order. Oxford: Oxford University Press: 40-50.

Maurer, Raimond, Olivia S. Mitchell, Ralph Rogalla, and Ivonne Siegelin. (2016b). "Accounting and Actuarial Smoothing of Retirement Payouts in Participating Life Annuities.” Insurance: Mathematics and Economics. 71: 268-283.

Maurer, Raymond, Olivia S. Mitchell, Ralph Rogalla, and Vasily Kartashov. (2013). "Lifecycle Portfolio Choice with Stochastic and Systematic Longevity Risk, and Variable Investment-Linked Deferred Annuities.” Journal of Risk and Insurance. 80(3): 649-676.

Mazzona, Fabrizio, and Franco Peracchi. (2018) "Self-Assessed Cognitive Ability and Financial Wealth: Are People Aware of their Cognitive Decline?” IEF Working Paper. http://www.eief.it/eief/images/WP_18.8.pdf

McGrath, Charles. (2020). “Cost of Retirement Increases in First Quarter.” Pensions and Investments. April 16. https://www.pionline.com/interactive/cost-retirement-increases-first-quarter?utm_source=p-iinvestments-topical-email\&utm_medium=email\&utm_cam\%E2\%80\%A6

Melbourne Mercer. (2019). Melbourne Mercer Global Pension Index 2019. Mercer LLC. https://www.mercer.com.au/our-thinking/mmgpi.html

Meredith, Sam. (2017). "Pensions Time-bomb for World's Biggest Economies Could Explode to $\$ 400$ Trillion, says WEF.” CNBC.com. https://www.cnbc.com/2017/05/26/pensions-time-bomb-forworlds-biggest-economies-could-explode-to-400-trillion-says-wef.html

Milevsky, Moshe. (2015). King William's Tontine: Why the Retirement Annuity of the Future Should Resemble Its Past. Cambridge: Cambridge University Press.

Mitchell, Olivia S. (1983). "Fringe Benefits and the Costs of Changing Jobs.” Industrial \& Labor Relations Review 37: 70-78.

Mitchell, Olivia S., P. Brett Hammond, and Stephen P. Utkus, eds. (2017). Financial Decision Making and Retirement Security in an Aging World. Oxford: Oxford University Press.

Mitchell, Olivia S. and Richard Shea, eds. (2016). Reimagining Pensions: The Next 40 Years. Oxford: Oxford University Press.

Mitchell, Olivia S., John Piggott, Michael Sherris, and Shaun Yow. (2006). "Financial Innovations for an Aging World.” In Demography and Financial Markets. C. Kent, A. Park, and D. Rees, eds. Report of the G-20 Meetings. Reserve Bank of Australia/Australian Treasury: Pegasus Press: 299-336.

Mitchell, Olivia S., John Piggott, and Noriyuke Takayama, eds. (2011). Revisiting Retirement Payouts: Market Developments and Policy Issues. Oxford: Oxford University Press.

Mitchell, Olivia S. and Stephen Utkus. (2020). “Target Date Funds and Portfolio Selection in 401(k) Plans.” NBER WP 17911.

Moffitt, Robert. (2020). “Can the US Safety Net Handle the COVID-19 Pandemic and Recession?” Johns Hopkins University Coronavirus Research Center report. https://coronavirus.jhu.edu/from-ourexperts/can-the-us-safety-net-handle-the-covid-19-pandemic-and-recession

Mogaji, Emmanuel. (2020). "Financial Vulnerability during a Pandemic: Insights for Coronavirus Disease (COVID-19).” University of Greenwich Research Agenda Working Paper 5: 57-63.

Moran, Gwen. (2020). “Coronavirus is Improving Employee Benefits and They May Stay That Way.” April 16. Fortune.com. https://fortune.com/2020/04/16/coronavirus-employee-benefits-sick-leavecovid-19/ 
Morgan Stanley. (2020). “Navigating Through the Perfect Storm: US Pension Deficit Hits \$619bn.” March 19, North American Insight.

Nossiter, Adam. (2020). “Macron Scraps Proposal to Raise Retirement Age in France.” New York Times. January 11.

O’Brien, Elizabeth. (2019). “Congress Just Passed the Biggest Retirement Bill in More Than a Decade. Here's What You Need to Know.” December 19. Money.com https://money.com/what-serure-actretirement-law-means-for-you/

OECD (nd). "Improving Pension System Coverage: Understanding and Meeting Needs." https://www.oecd.org/daf/fin/private-pensions/43920158.pdf

OECD (2015). The OECD Roadmap for the Good Design of Defined Contribution Pension Plans. http://www.oecd.org/finance/private-pensions/50582753.pdf

OECD (2019). Pensions at a Glance 2019: OECD and G20 Indicators, OECD Publishing, Paris, https://doi.org/10.1787/b6d3dcfc-en.

Oxfam. (2020). How to Confront the Coronavirus Catastrophe. Oxfam Media Briefing 30 March. https://www.oxfam.org/en/research/how-confront-coronavirus-catastrophe

Pardes, Arielle. (2020). "This Pandemic is a 'Fork in the Road' for Gig Worker Benefits." April 9. Wired.com. https://www.wired.com/story/gig-worker-benefits-covid-19-pandemic/

Pension Policy International (PPI). (2020). "More Than 1 Billion Workers Face 'Drastic' Hit From Virus.” PensionPolicyInternational.com. https://pensionpolicyinternational.com/more-than-1-billionworkers-face-drastic-hit-from-virus/?utm_source=PP+Weekly+NL\&utm_campaign=2e6ac2debdEMAIL_CAMPAIGN_2020_04_08_02_55\&utm_medium=email\&utm_term=0_90844fbcc52e6ac2debd-84357265.

Pielichata, Pauline. (2020). "PEPPs Unlikely to Survive after Closer Look by EU Regulators.” Pionline.com. March 9. https://www.pionline.com/special-report-retirement-plans-future/pepps-unlikelysurvive-after-closer-look-eu-regulators?utm_source=p-i-definedcontribution\&utm_medium=email\&utm_campaign=20200309\&utm_content=article8headline\&CSAuthResp=1583765626050\%3A0\%3A36658\%3A455\%3A24\%3Asuccess\%3A3B9 FB55A07FEA70AF216E81F3735D31C\#cci_r=36658

Plater, Roz. (2020). “As Many as 50 Percent of People with COVID-19 Aren’t Aware They Have the Virus.” April 16. Healthline.com. https://www.healthline.com/health-news/50-percent-of-people-withcovid19-not-aware-have-virus

Poterba, James. (2014). "Retirement Security in an Aging Population.” American Economic Review: Papers \& Proceedings 104(5): 1-30

Quinn, Joseph F., and Kevin E. Cahill. (2017). "Challenges and Opportunities of Living and Working Longer.” In How Persistent Low Returns Will Shape Saving and Retirement. Olivia S. Mitchell, Robert Clark, and Raimond Maurer, eds. Oxford: Oxford University Press, 101-118,

Rappaport, Anna and Andrew Peterson. (2016). "Risk Sharing Alternatives for Pension Plan Design: An Overview and Case Studies.” In Reimagining Pensions: The Next 40 Years. Olivia S. Mitchell and Richard Shea, eds. Oxford: Oxford University Press: 95-123.

Rauh, Joshua. (2017). "Hidden Debt, Hidden Deficits: 2017 Edition: How Pension Promises Are Consuming State and Local Budgets.” Palo Alto, CA: Hoover Institution.

Robertson, Campbell and Robert Gebeloff. (2020). "How Millions of Women Became the Most Essential Workers in America.” April 18. NYT.com. https://www.nytimes.com/2020/04/18/us/coronaviruswomen-essentialworkers.html?campaign_id=9\&emc=edit_nn_20200419\&instance_id=17774\&nl\%E2\%80\%A6

Rosen, Maya Haran, and Orly Sade. (2019). "Investigating the Introduction of a Regulatory Fintech Advancement Designed to Reduce Limited Attention Regarding Inactive Saving Accounts - Data, Survey, and Field Experiment.” https://ssrn.com/abstract=2929674

Ross, Arthur. (1958). “Do We Have a New Industrial Feudalism?” American Economic Review 48(5): 903920. 
Santucci, Larry. (2019). “Aging, Cognition, and Financial Health: Building a Robust System for Older Americans.” Conference Summary. Consumer Finance Institute, Federal Reserve of Philadephia. https://econpapers.repec.org/article/fipfedpcs/0001.htm

Schlecter, Hans, Arturo Cifuentes, and Bernando Pagnoncelli. (2019). "Pension Funds in Mexico and Chile: A Risk-Reward Comparison.” https://www.researchgate.net/publication/331982579_Pension_Funds_in_Mexico_and_Chile_A_ Risk-Reward_Comparison/link/5c98de8145851506d72a8c88/download

Scism, Leslie and Drew Hinshaw. (2020). "Pandemic Insurance for Poor Countries Pays Out \$195.8 Million.” WSJ.com. May 15. https://www.wsj.com/articles/pandemic-insurance-for-poorcountries-pays-out-195-8-million-11589544010

SimplyWise. (2020). "New Study: 4 in 10 Americans at Risk of Delaying Retirement." https://www.simplywise.com/blog/study-4-in-10-may-delay-retirement/

Singh, Dhara. (2020). "Half of Americans took from retirement savings or plan to amid pandemic, survey finds.” Yahoo.com. May 15. https://money.yahoo.com/half-of-americans-took-from-retirement-savingsor-plan-to-amid-pandemic-190220591.html

Slok, Torsten. (2020). “Global Macro Outlook: Virus Curve Flattening Out and Recession Curve Flattening Out.” Deutsche Bank Research, April 4.

Social Security Trustees (2020). 2020 Annual Report of the Board of Trustees of the Federal Old-Age and Survivors Insurance and Federal Disability Insurance Trust Funds.” April 22. https://www.ssa.gov/OACT/TR/2020/tr2020.pdf

Stankiewicz, Kevin. (2020). "World Bank President Warns the Global Coronavirus Recession Will Hurt Poorer Countries the Most.” April 15. CNBC.com. https://www.cnbc.com/2020/04/15/world-bankpresident-david-malpass-recession-to-hurt-poorcountries-most.html

Steverman, Ben. (2019). “Retirees Might Run out of Money before They Die.” Bloomberg.com. June 13. https://www.bloomberg.com/news/articles/2019-06-13/world-s-retirees-risk-running-outofmoney-a-decade-before-death

Tang, Ning, Olivia S. Mitchell and Stephen P. Utkus. (2012). "Trading in 401(k) Plans during the Financial Crisis.” Retirement Security and the Financial and Economic Crisis: An Overview.” In Reshaping Retirement Security: Lessons from the Global Financial Crisis. R. Maurer, O.S. Mitchell, and M. Warshawsky, eds. Oxford: Oxford University Press: 101-119.

Tergesen, Anne. (2019). "Senate Spending Bill Includes Significant Changes to U.S. Retirement System.” Dec. 19. New York Times. https://www.wsj.com/articles/senate-spending-bill-includes-significantchanges-to-u-s-retirement-system-11576780736?mod=djemalertNEWS

United Auto Workers (UAW). (2018). Work or Retire? Making a Good Decision with your UAW-GM Pension. Books/GM_Work_or_Retire.pdf

van Alfen, Sameer. (2020). “WTW: Dutch Schemes’ Funding Ratios Could Dip Under 70\%.” IPE.com, 6 April. "https://www.ipe.com/news/wtw-dutch-schemes-funding-ratios-could-dip-under70/10044793.article.

Voss, Rob, Will Marte, and David Laborde. (2002). "How much will global poverty increase because of COVID-19?” March 20. IFPRI.org. https://www.ifpri.org/blog/how-much-will-global-povertyincrease-because-covid-19

Whitehouse, Edward. (2005). "The Tax Treatment of Funded Pensions.” World Bank Pension Reform Primer Series. Washington, DC: World Bank. https://openknowledge.worldbank.org/handle/10986/11211

Wilcox Volz, Beagan. (2020). "Strapped Companies to Suspend 401(k) Matches.” March 30. Ignites.com. https://www.ignites.com/c/2701453/330923/strapped_companies_suspend_matches?referrer_mod ule=emailMostPopular\&module_order=15\&code=YldsMFkyaGxiRzlBZDJoaGNuUnZiaTUxY0 dWdWJpNWxaSFVzSURJM01EQTVOaXdnTVRVd01Ea3hPRFUyTnc9PQ 
Wollman Rusoff, Jane. (2002). “Wade Pfau: Pandemic Tears Up 4\% Rule.” April 14. ThinkAdvisor.com https://www.thinkadvisor.com/2020/04/14/wade-pfau-virus-crisis-has-slashed-4-rule-nearly-inhalf/

Wood, Johnny. (2020). "This is How Europe Is Helping Companies and Workers As the Coronavirus Deepens.” March 16. World Economic Forum. https://www.weforum.org/agenda/2020/03/covid19-quarantine-sick-pay/

World Economic Forum. (WEF 2017). “We’ll Live to 100 - How Can We Afford It?” White Paper. http://www3.weforum.org/docs/WEF_White_Paper_We_Will_Live_to_100.pdf

Wrobel, Sharon. (2019). "Self-employed to get mandatory pension." Jerusalem Post. November 30. https://www.jpost.com/Business/Self-employed-to-get-mandatory-pension

Yong, Ed. (2020). "How the Pandemic Will End." Atlantic, March 25. https://www.theatlantic.com/health/archive/2020/03/how-will-coronavirus-end/608719/

Zeng, M. (2017). US 10-Year Note Yield Hits Low for the Month. WallStreetJournal.com. March 31. https://www.wsj.com/articles/u-s-bonds-rebound-from-earlier-losses-1490108750?tesla=y 
Figure 1. Estimated Retirement Savings Gaps In Six Developed Nations, Pre-COVID-19

U.S.
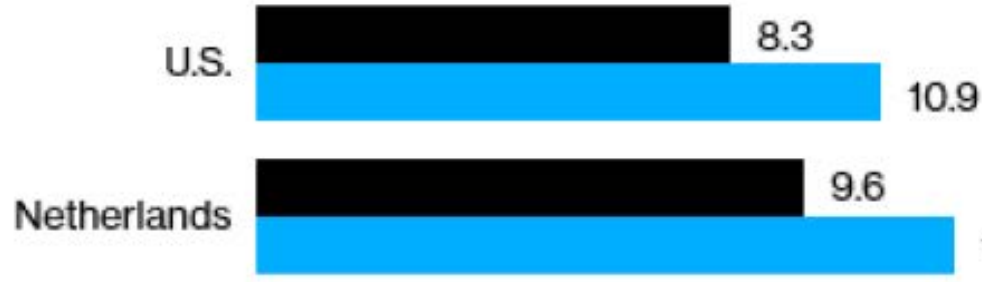

12.2

U.K.

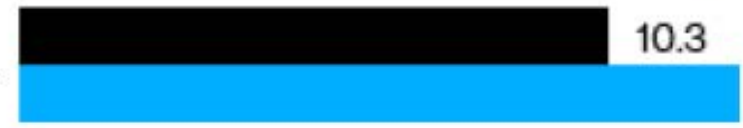

12.6

Australia

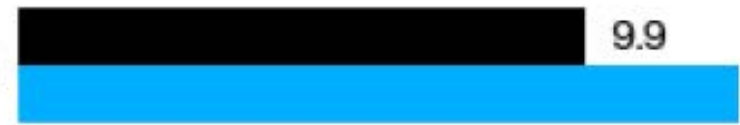

12.6

Canada

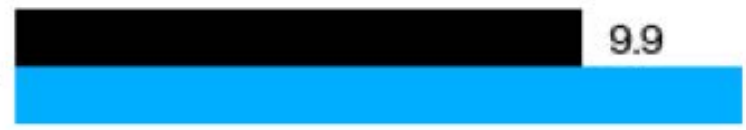

\section{7}

Japan

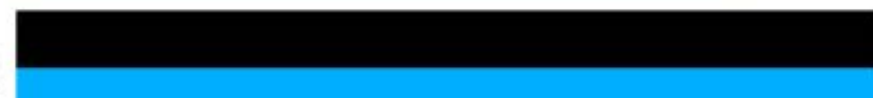

15.1

Note: Black bar reflects how many years of assets retirees have to live on; blue bar refers to life expectancy at retirement. Source: Steverman (2019)

Figure 2. Retirement Saving Needed to Generate \$1/year of Retirement Payouts for 25 Years: Each vintage reflects a target year for retirement.

December '19 March '20

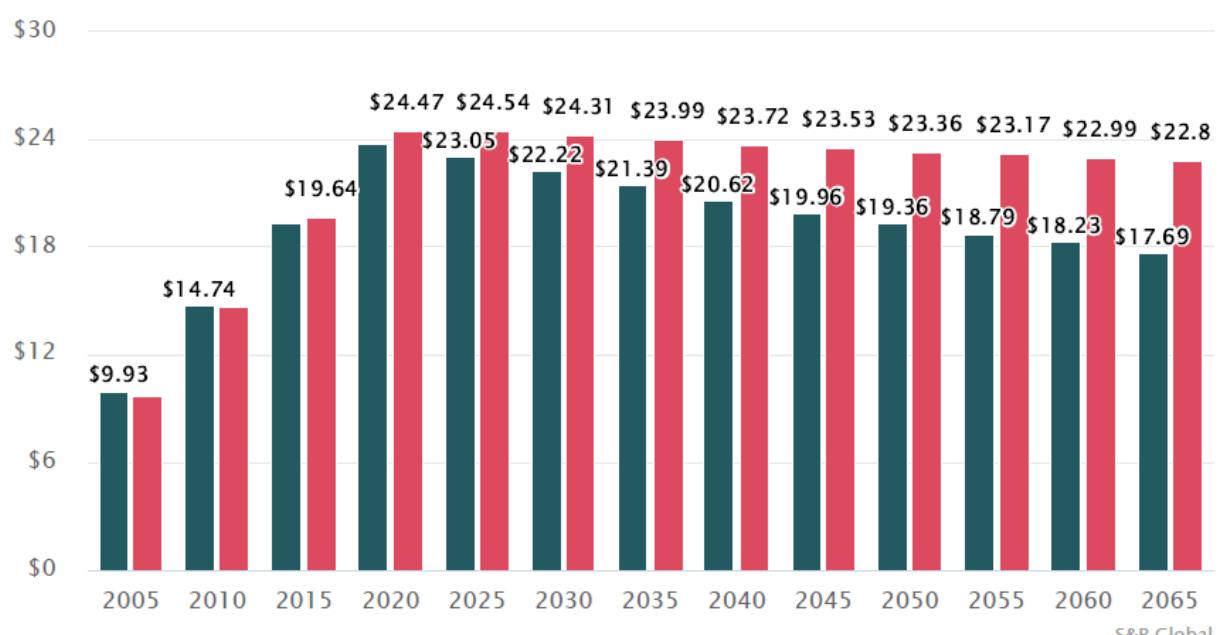


Note: This figure indicates how much a retiree in each year would need to have saved, in order to generate one dollar in benefit payouts for the next 25 years. Projections calculated by S\&P Dow Jones using a liability driven investment strategy focused on inflation-adjusted retirement income. Source: McGrath (2020). 
Figure 3. Preparedness for Healthcare Costs in Retirement, Pre-COVID-19

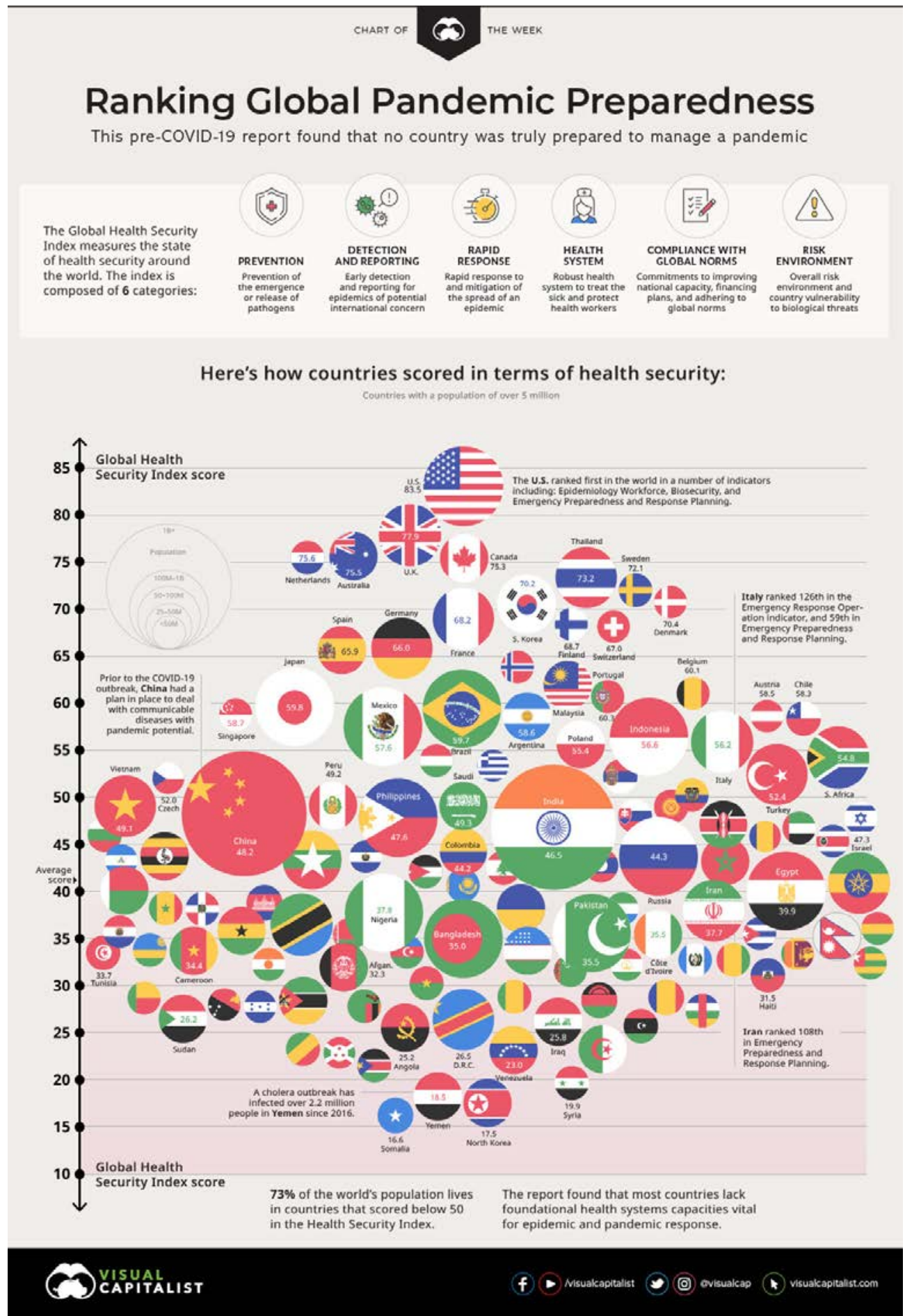

Source: WEF https://www.weforum.org/agenda/2020/03/coronavirus-developing-countries-inequalitydebt-oxfam/ 
Figure 4. Social Insurance Programs Launched or Extended in Response to COVID-19

A. March 15 versus March 27, 2020
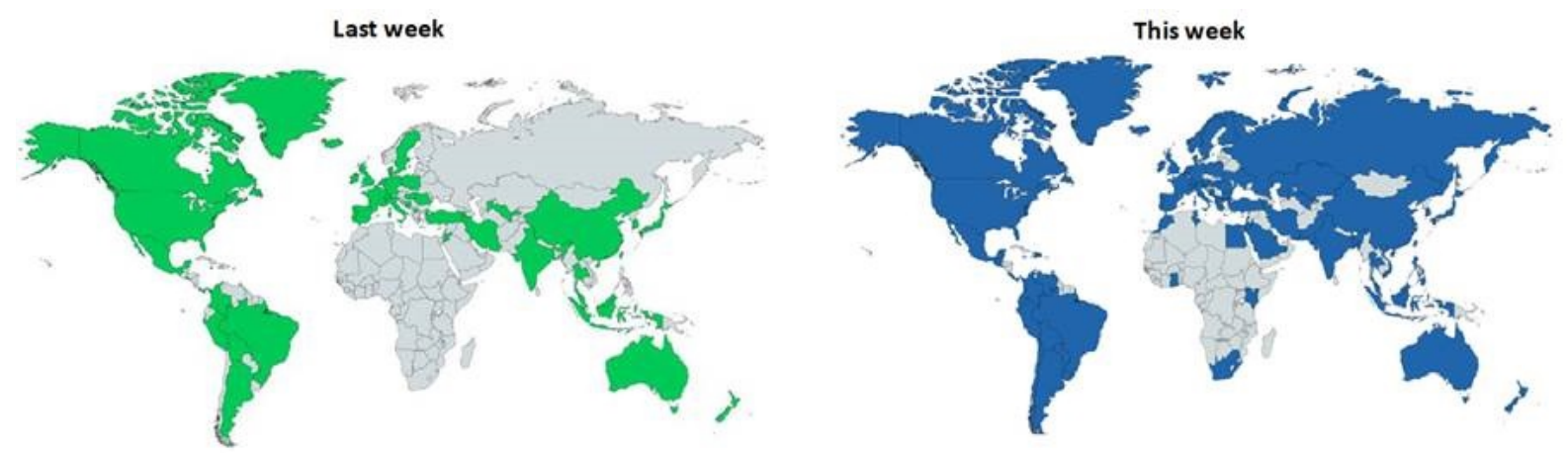

B. Types of Social Assistance Programs Adopted or Extended

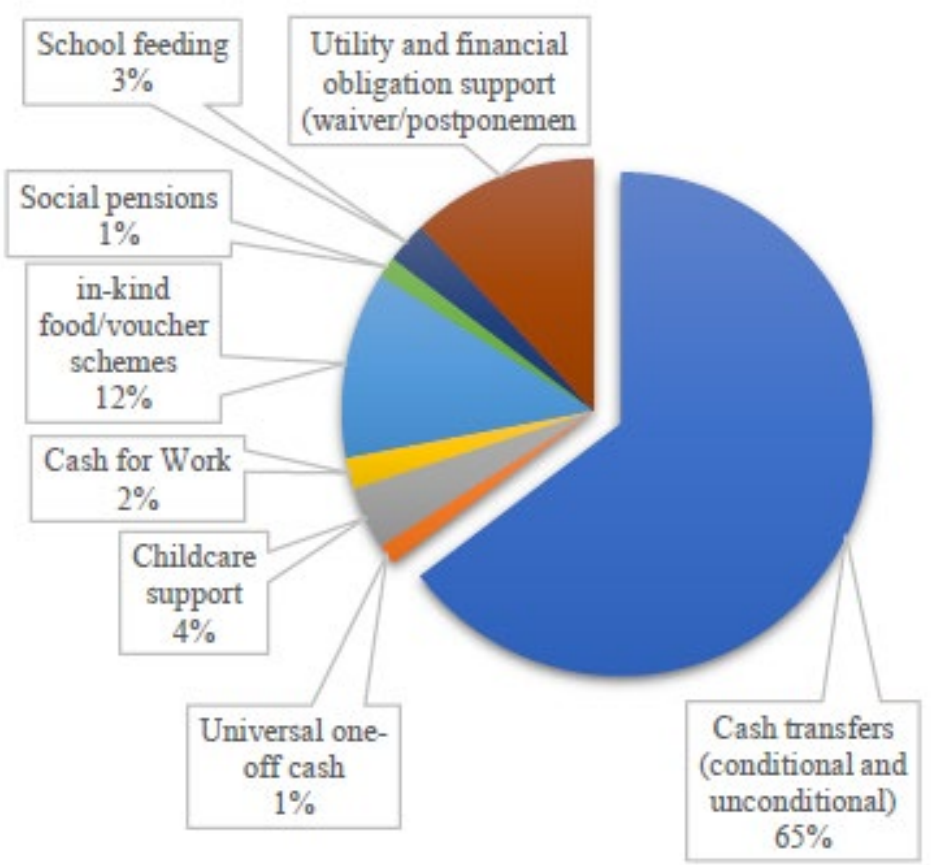

Source: Gentilini et al. (2020) 
Figure 5. Working From Home: Some Occupations Can, but Others Cannot

Working primarily from home is already common in some occupations Full-time employees primanily working from home as a percent of total full-time employment by detailed occupation, 2018

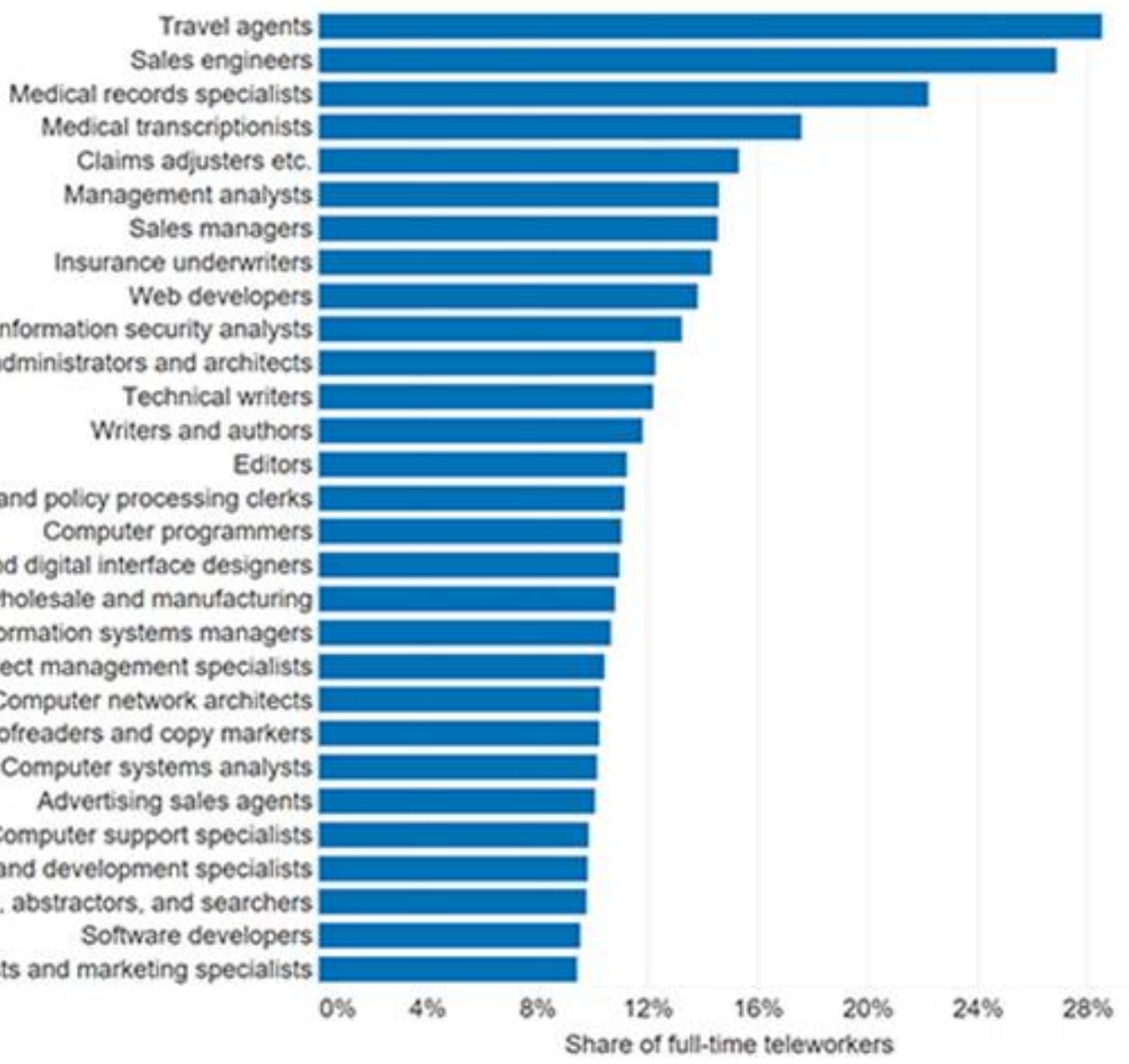

Source: Levanon et al. (2020). 


\section{Figure 6. Labor Markets May Take Longer to Recover Where Many Rely on Public Transportation}

The share of workers commuting to work using public transportation, 2018

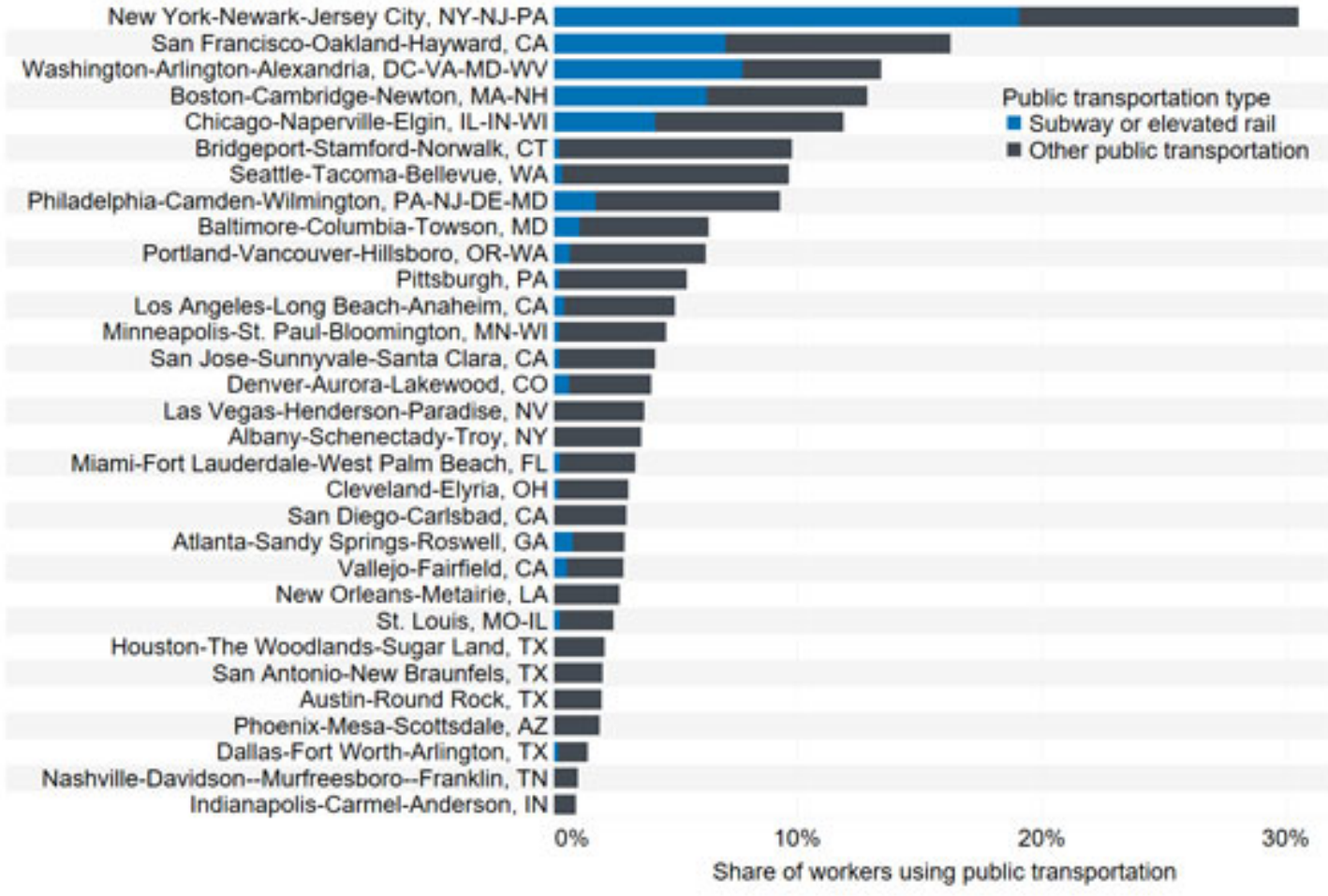

Source: Levanon et al. (2020). 
Figure 7. Continued Population Aging Likely

A. Rising Longevity Around the Globe

\section{The world's centenarian population projected to grow rapidly}

Number of persons ages 100 and older

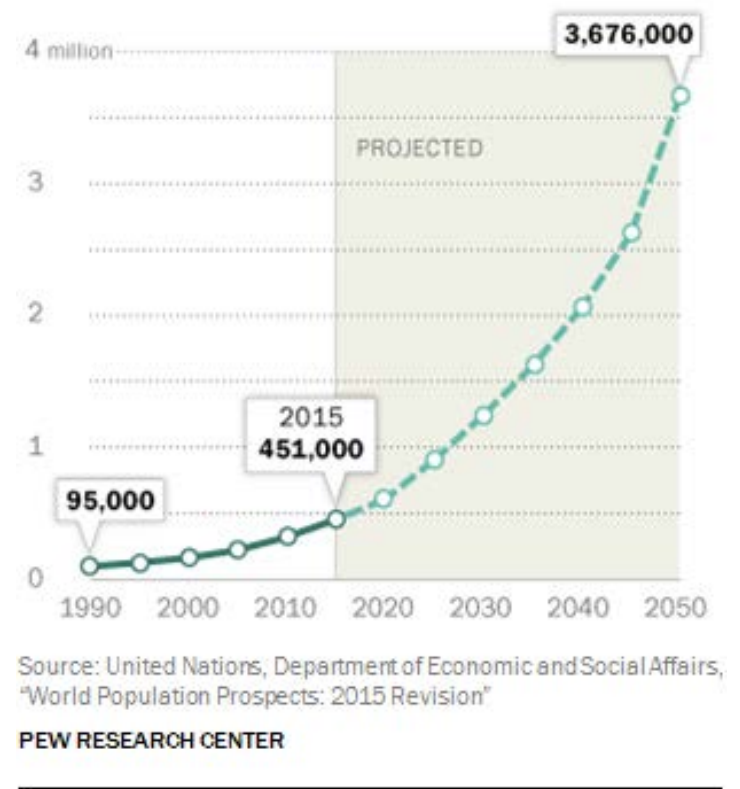

Source: Stepler (2016).

\section{B. Mortality Levelling Off at Advanced Ages}

\section{LONGEVITY UNLIMITED}

A person's chances of dying tend to increase throughout adulthood, but a model based on data from 3,836 people aged 105 or older predicts that this trend flattens out in the very elderly.

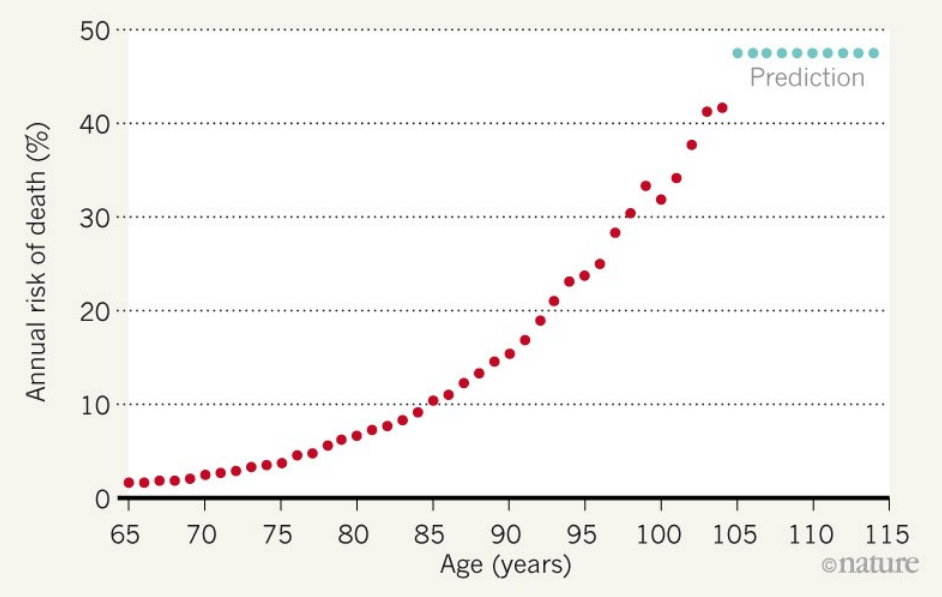

Source: Dolgin (2018) 
Figure 8. Comparison of Employee Benefits Offered Across The EU and U.S.

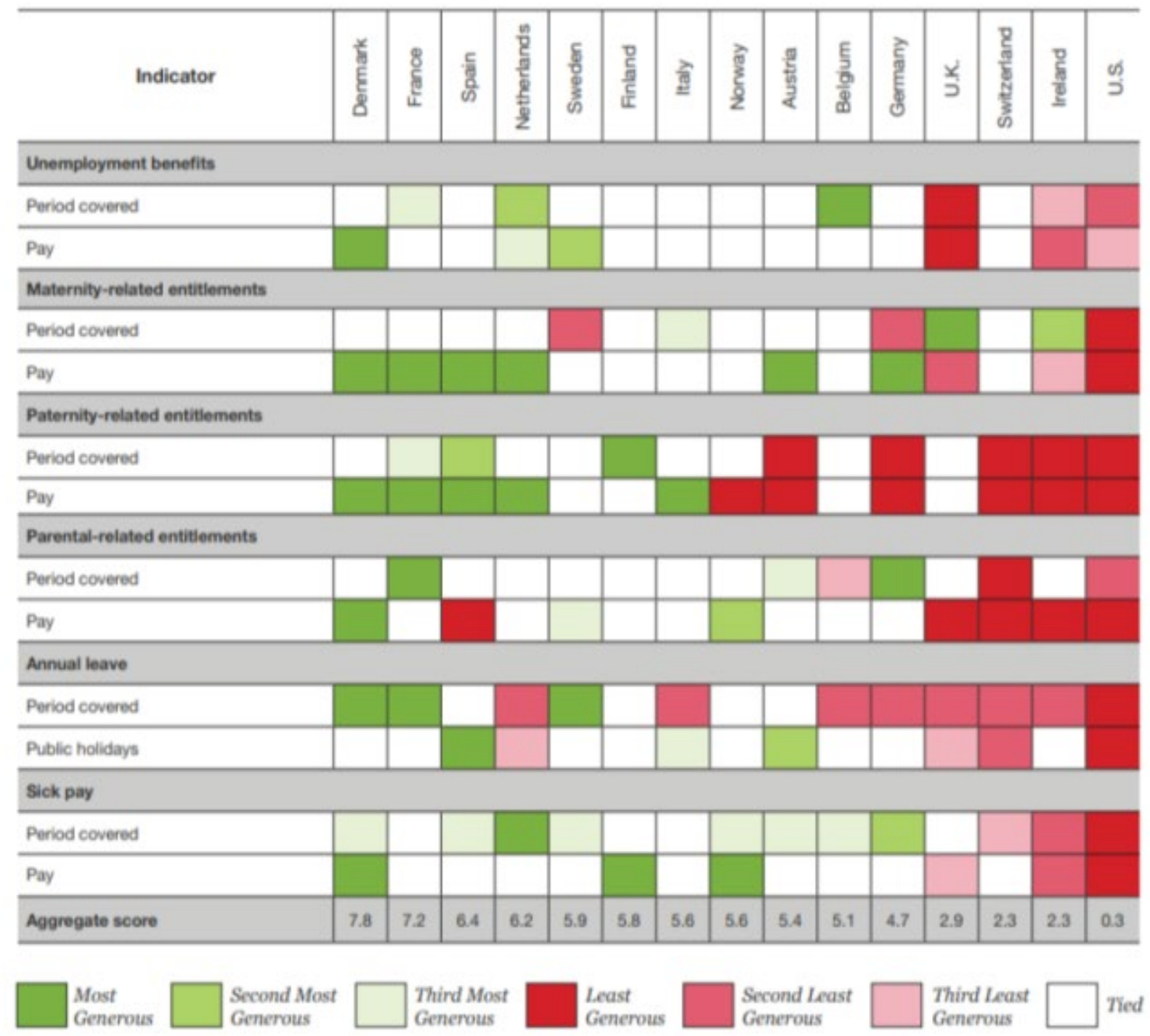

Source: Gross (2020). 
Figure 9. Extreme Poverty Rising with Declining Economic Growth, Post-COVID-19

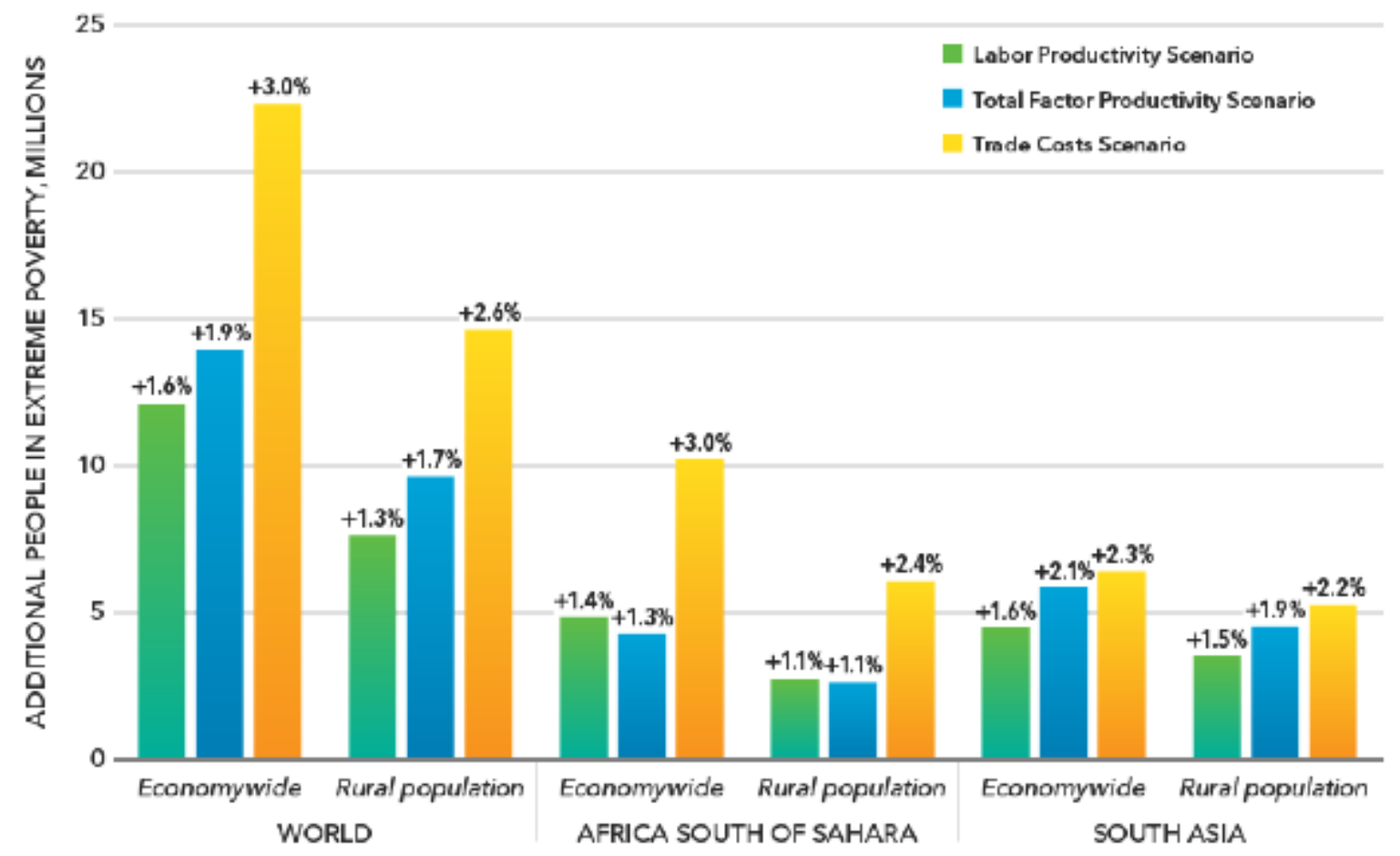

Source: MIRAGRODEP simulations

Notes: PPP - purchasing power parity. The percentages above each bar in the graph refer to the percent change from the base number of poor.

IFPRI

The simulation results for the poverty impacts by region show some sensitivity to the nature of the transmission channel. In absolute terms, the greatest regional poverty impact would fall on Africa south of the Sahara, where $40-50 \%$ of the global poverty increase would be concentrated. In relative terms, the impact of a trade shock would affect Africa's poor more than South Asia's, given that Africa's economies are - on average-more dependent on trade than those of South Asia, given the weight of India, a large but relatively closed economy. The productivity shocks, in contrast, would have a bigger impact on poverty in South Asia than in Africa, possibly because of the bigger adverse impact in the scenarios on non-agricultural sectors, which have a larger weight in South Asian economies.

Note: Evolution of the number of people in extreme poverty (PPP\$1.90/day poverty threshold) in the event of a 1\% reduction in global economic growth. Source: Voss et al. (2020). 
Figure 10. Changes in Self-Employment over Time, Pre-COVID-19

Index of self-employment as a proportion of total employment $(2003=100)$

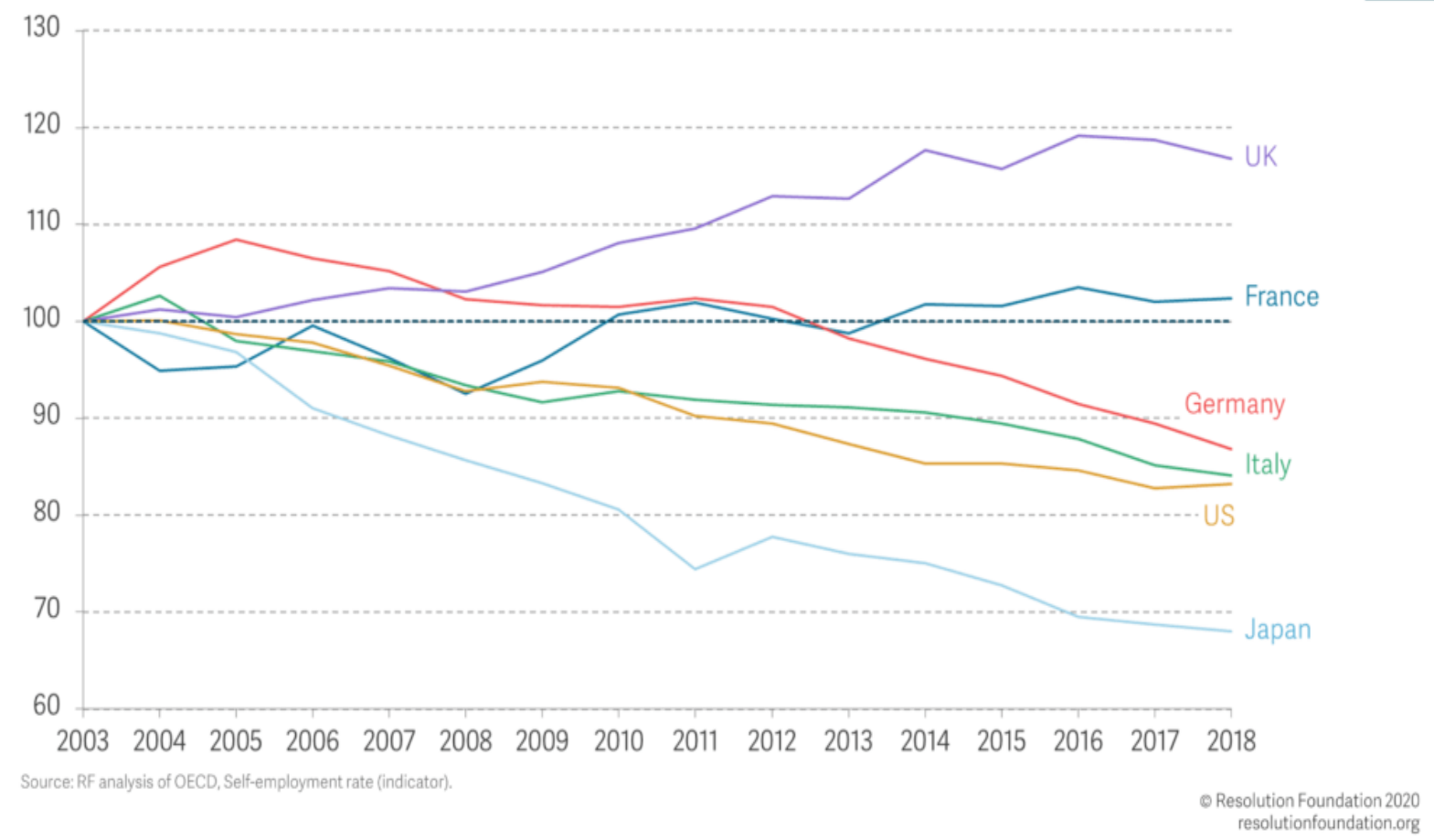

Source: Bell and Slaughter (2020). 
Table 1. Melbourne Mercer Pension Sustainability Index Rankings, Pre-COVID-19

\begin{tabular}{|c|c|c|c|}
\hline Grade & Index Value & Systems & Description \\
\hline A & $>80$ & $\begin{array}{l}\text { Netherlands } \\
\text { Denmark }\end{array}$ & $\begin{array}{l}\text { A first class and robust retirement income system that delivers good } \\
\text { benefits, is sustainable and has a high level of integrity. }\end{array}$ \\
\hline $\mathrm{B}+$ & $75-80$ & Australia & \\
\hline B & $65-75$ & $\begin{array}{l}\text { Finland } \\
\text { Sweden } \\
\text { Norway } \\
\text { Singapore } \\
\text { New Zealand } \\
\text { Canada } \\
\text { Chile } \\
\text { Ireland } \\
\text { Switzerland } \\
\text { Germany }\end{array}$ & $\begin{array}{l}\text { A system that has a sound structure, with many good features, but has } \\
\text { some areas for improvement that differentiates it from an A-grade system. }\end{array}$ \\
\hline $\mathrm{C}+$ & $60-65$ & $\begin{array}{l}\text { UK } \\
\text { Hong Kong SAR } \\
\text { USA } \\
\text { Malaysia } \\
\text { France }\end{array}$ & \\
\hline C & $50-60$ & $\begin{array}{l}\text { Peru } \\
\text { Colombia } \\
\text { Poland } \\
\text { Saudi Arabia } \\
\text { Brazil } \\
\text { Spain } \\
\text { Austria } \\
\text { South Africa } \\
\text { Italy } \\
\text { Indonesia }\end{array}$ & $\begin{array}{l}\text { A system that has some good features, but also has major risks and/or } \\
\text { shortcomings that should be addressed. Without these improvements, } \\
\text { its efficacy and/or long-term sustainability can be questioned. }\end{array}$ \\
\hline D & $35-50$ & $\begin{array}{l}\text { Korea } \\
\text { China } \\
\text { Japan } \\
\text { India } \\
\text { Mexico } \\
\text { Philippines } \\
\text { Turkey } \\
\text { Argentina } \\
\text { Thailand }\end{array}$ & $\begin{array}{l}\text { A system that has some desirable features, but also has major weaknesses } \\
\text { and/or omissions that need to be addressed. Without these improvements, } \\
\text { its efficacy and sustainability are in doubt. }\end{array}$ \\
\hline $\mathrm{E}$ & $<35$ & Nil & A poor system that may be in the early stages of development or non-existent. \\
\hline
\end{tabular}

None of these systems has an E-grade system, which would be represented by an index value below 35. A score between 35 and 50, representing a D-grade system, indicates a system that has some sound features but there also exist major omissions or weaknesses. A D-grade classification may also occur in the relatively early stages of the development of a particular retirement income system.

Source: Melbourne Mercer (2019). 
Table 2. DC Plan Annual Contribution Rates Required to Generate Retirement Income Stream at age 65 Worth Half of Pre-Retirement Income, by Real Return and Accumulation Period

\begin{tabular}{lcccccc}
\hline \hline & & \multicolumn{2}{c}{ Men } & & \multicolumn{2}{c}{ Women } \\
\cline { 3 - 4 } \cline { 5 - 6 } Working & Real & $\begin{array}{c}\text { Nominal } \\
\text { annuity }\end{array}$ & $\begin{array}{c}3 \% \text { increasing } \\
\text { annuity }\end{array}$ & & $\begin{array}{c}\text { Nominal } \\
\text { annuity }\end{array}$ & $\begin{array}{c}3 \% \text { increasing } \\
\text { annuity }\end{array}$ \\
\hline 20 & 0.02 & 32.7 & 44.3 & 35.3 & 48.2 \\
30 & 0.02 & 20.7 & 28.1 & & 22.4 & 30.5 \\
40 & 0.02 & 14.8 & 20.0 & 15.9 & 21.7 \\
20 & 0.03 & 27.7 & 37.5 & & 29.9 & 40.8 \\
30 & 0.03 & 17.6 & 23.9 & & 19.0 & 26.0 \\
40 & 0.03 & 11.9 & 16.1 & & 12.8 & 17.5 \\
20 & 0.04 & 26.4 & 35.7 & & 28.4 & 38.8 \\
30 & 0.04 & 14.9 & 20.2 & & 16.1 & 22.0 \\
40 & 0.04 & 9.4 & 12.8 & & 10.2 & 13.9 \\
\hline
\end{tabular}

Source: Poterba (2014). 